\title{
Identification and Geological Significance of Early Jurassic Adakitic Volcanic Rocks in Xintaimen Area, Western Liaoning
}

\author{
Zhi-Wei Song ${ }^{1}$, Chang-Qing Zheng ${ }^{1,2, *}$, Chen-Yue Liang ${ }^{1,2}{ }^{\oplus}$, Bo Lin ${ }^{1}$, Xue-Chun Xu ${ }^{1}$, Quan-Bo Wen ${ }^{1}$, \\ Ying-Li Zhao ${ }^{1}$, Cheng-Gang Cao ${ }^{3}$ and Zhi-Xin Wang ${ }^{4}$ \\ 1 College of Earth Sciences, Jilin University, Changchun 130061, China; Songzw19@mails.jlu.edu.cn (Z.-W.S.); \\ chenyueliang@jlu.edu.cn (C.-Y.L.); linbo_nwpb@163.com (B.L.); xuxuechun@jlu.edu.cn (X.-C.X.); \\ wenquanbo@163.com (Q.-B.W.); yingliz@jlu.edu.cn (Y.-L.Z.) \\ 2 Key Laboratory of Mineral Resources Evaluation in Northeast Asia, Ministry of Land and Resources, \\ Jilin University, Changchun 130061, China \\ 3 Qinghai Bureau of Environmental Geology Exploration, Xining 810008, China; ccg220503@126.com \\ 4 Shandong No.3 Exploration Institute of Geology and Mineral Resources, Yantai 264000, China; \\ wzx61050304@126.com \\ * Correspondence: zhengchangqing@jlu.edu.cn; Tel.: +86-13894881089
}

check for

updates

Citation: Song, Z.-W.; Zheng, C.-Q.; Liang, C.-Y.; Lin, B.; Xu, X.-C.; Wen, Q.-B.; Zhao, Y.-L.; Cao, C.-G.; Wang, Z.-X. Identification and Geological Significance of Early Jurassic Adakitic Volcanic Rocks in Xintaimen Area, Western Liaoning. Minerals 2021, 11, 331. https://doi.org/10.3390/ $\min 11030331$

Academic Editor: Tamara Bayanova

Received: 4 February 2021

Accepted: 18 March 2021

Published: 23 March 2021

Publisher's Note: MDPI stays neutral with regard to jurisdictional claims in published maps and institutional affiliations.

Copyright: (c) 2021 by the authors. Licensee MDPI, Basel, Switzerland. This article is an open access article distributed under the terms and conditions of the Creative Commons Attribution (CC BY) license (https:// creativecommons.org/licenses/by/ $4.0 /)$.

\begin{abstract}
The Western Liaoning area, where a large number of Jurassic-Cretaceous volcanic rocks are exposed, is one of the typical areas for studying the Mesozoic Paleo-Pacific and Mongolia-Okhotsk subduction process, and lithospheric destruction of North China Craton. The identification and investigation of Early Jurassic adakitic volcanic rocks in the Xintaimen area of Western Liaoning is of particular significance for exploring the volcanic magma source and its composition evolution, tracking the crust-mantle interaction, and revealing the craton destruction and the subduction of oceanic plates. Detailed petrography, zircon U-Pb dating, geochemistry, and zircon Hf isotope studies indicate that the Early Jurassic intermediate-acidic volcanic rocks are mainly composed of trachydacites and a few rhyolites with the formation ages of 178.6-181.9 Ma. Geochemical characteristics show that they have a high content of $\mathrm{SiO}_{2}, \mathrm{MgO}, \mathrm{Al}_{2} \mathrm{O}_{3}$, and total-alkali, typical of the high-K calc-alkaline series. They also show enrichment of light rare earth elements (LREEs) and large ion lithophile elements (LILEs), depletion of heavy rare earth elements (HREEs) and high field strength elements (HFSEs), and have a high content of $\mathrm{Sr}$ and low content of $\mathrm{Y}$ and $\mathrm{Yb}$, suggesting that they were derived from the partial melting of the lower crust. The $\varepsilon_{\mathrm{Hf}}(\mathrm{t})$ values of dated zircons and two-stage model ages ( $\mathrm{T}_{\mathrm{DM} 2}$ ) vary from -11.6 to -7.4 and from 1692 to $1958 \mathrm{Ma}$, respectively. During the Early Jurassic, the study area was under long-range tectonic effects with the closure of the Mongolia-Okhotsk Ocean and the subduction of the Paleo-Pacific plate, which caused the basaltic magma to invade the lower crust of the North China Craton. The mantle-derived magma was separated and crystallized while heating the Proterozoic lower crust, and part of the thickened crust melted to form these intermediate-acidic adakitic volcanic rocks.
\end{abstract}

Keywords: adakite; zircon U-Pb age; North China Craton; Western Liaoning; Paleo-Pacific plate

\section{Introduction}

Adakite has attracted much attention due to its unique magma source, geodynamic significance, and close relationship with metal deposits. The term "adakite" originally refers to a set of intermediate-acidic igneous rocks formed by slab melting in the subduction environment, with geochemical characteristics of $\mathrm{MgO} \leq 3 \mathrm{wt}$.\%, $\mathrm{SiO}_{2} \geq 56 \mathrm{wt}$ \%, $\mathrm{Al}_{2} \mathrm{O}_{3} \geq 15$ wt.\%, La/Yb $\geq 20, \mathrm{Sr} / \mathrm{Y} \geq 40$, and/or low $\mathrm{Y} \leq 18$ ppm [1-4]. However, some intermediate-acidic igneous rocks with the geochemical characteristics of adakite are not necessarily developed in an island arc environment or by the melting of subducted slabs [5-11]. These rocks are collectively referred to as adakitic rocks. In this study, a set of intermediate-acidic adakitic volcanic rocks with high-K calc-alkaline series affinity were 
identified in the Western Liaoning area, which is located on the northern margin of the North China Craton (NCC; Figure 1).

As one of the oldest cratons in the world, the NCC has a long history of $\sim 3.8$ billion years, which preserves a relatively complete tectonic evolution that contains metamorphic basement from Archean to Paleoproterozoic and Phanerozoic caprock development (Figure 1) [12-19]. The Western Liaoning is located in the northern margin of the NCC and the eastern part of the Yanshan tectonic belt which developed a large number of Mesozoic volcanic-sedimentary basins with lots of lacustrine paleontological fossils. Therefore, Western Liaoning is one of the classic areas to study the Mesozoic tectonic-magma and biological evolution in the NCC (Figures 1 and 2) [6,18,20-26].

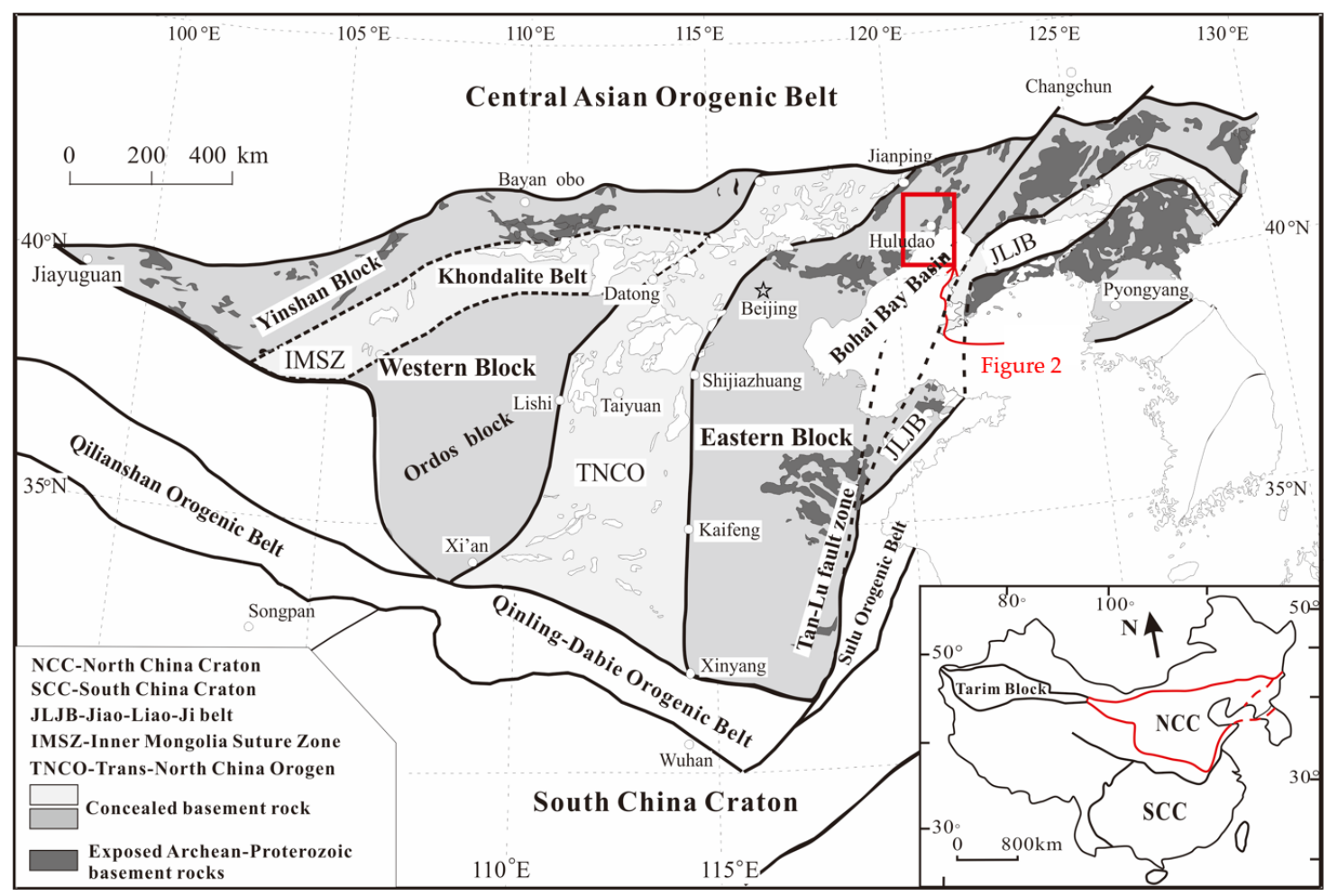

Figure 1. Simplified map showing the tectonic subdivisions of the North China Craton and the distribution of the basement rocks (modified after Zhao et al. [13]; NCC for North China Craton, SCC for South China Craton).

Since the Mesozoic, the Western Liaoning region was affected by the superimposition of the NE trending Paleo-Pacific plate tectonic domain, Mongolia-Okhotsk tectonic domain and the nearly EW trending Central Asian Orogenic Belt (CAOB). In complex tectonic regimes, the wide development of Mesozoic volcanic rocks began in the Early Jurassic and ended in the late Early Cretaceous. Geochronology of the Mesozoic volcanic events in the Western Liaoning region have been studied in detail by predecessors, which can be divided into four phases: Early Jurassic (Nandaling or Xinglonggou Period), Late Jurassic (Tiaojishan or Lanqi Period), Early Cretaceous (Zhangjiakou or Yixian Period), and Late Cretaceous (Daxingzhuang Period) $[6,24,27-37]$. However, most of the geochronological and biological studies focused on the Late Jurassic-Early Cretaceous magmatic events, and most scholars believed that the Late Jurassic magmatic rocks may be the result of the Paleo-Pacific subduction $[6,20,21]$ or the combined influence of the subduction and closure of the Mongolia-Okhotsk Ocean [38-40]. The widely distributed Early Cretaceous magmatic rocks were formed under a strong extensional background, which was related to the subduction of the Paleo-Pacific plate $[20,21,25,26,40,41]$. However, the distribution and tectonic setting of the Early Jurassic volcanic rocks are still controversial $[6,36,37,39,42,43]$. 
A wide range of volcanic rocks was exposed in the Xintaimen area, Western Liaoning region, but the only research was mostly focused on the Yanliao biota and Jehol biota which occur in this area [44-47], and their ages were roughly defined as the middle and late Early Cretaceous. However, detailed fieldwork has found that the large-scale Early Jurassic adakitic volcanic rocks now identified in the Western Liaoning region, previously were rarely reported and were included in the middle and late Early Cretaceous biota divisions. This paper conducts a systematic study on the Early Jurassic volcanic rocks, including petrology, geochemistry, zircon $\mathrm{U}-\mathrm{Pb}$ chronology, and Lu-Hf isotope analysis, and then discusses its magma origin, petrogenesis, and crust-mantle interaction, all of which provide a key position and important window for understanding the subduction process of the Paleo-Pacific plate and the superposition, conversion, and transformation of different tectonic regimes (Figure 1) [48-51].

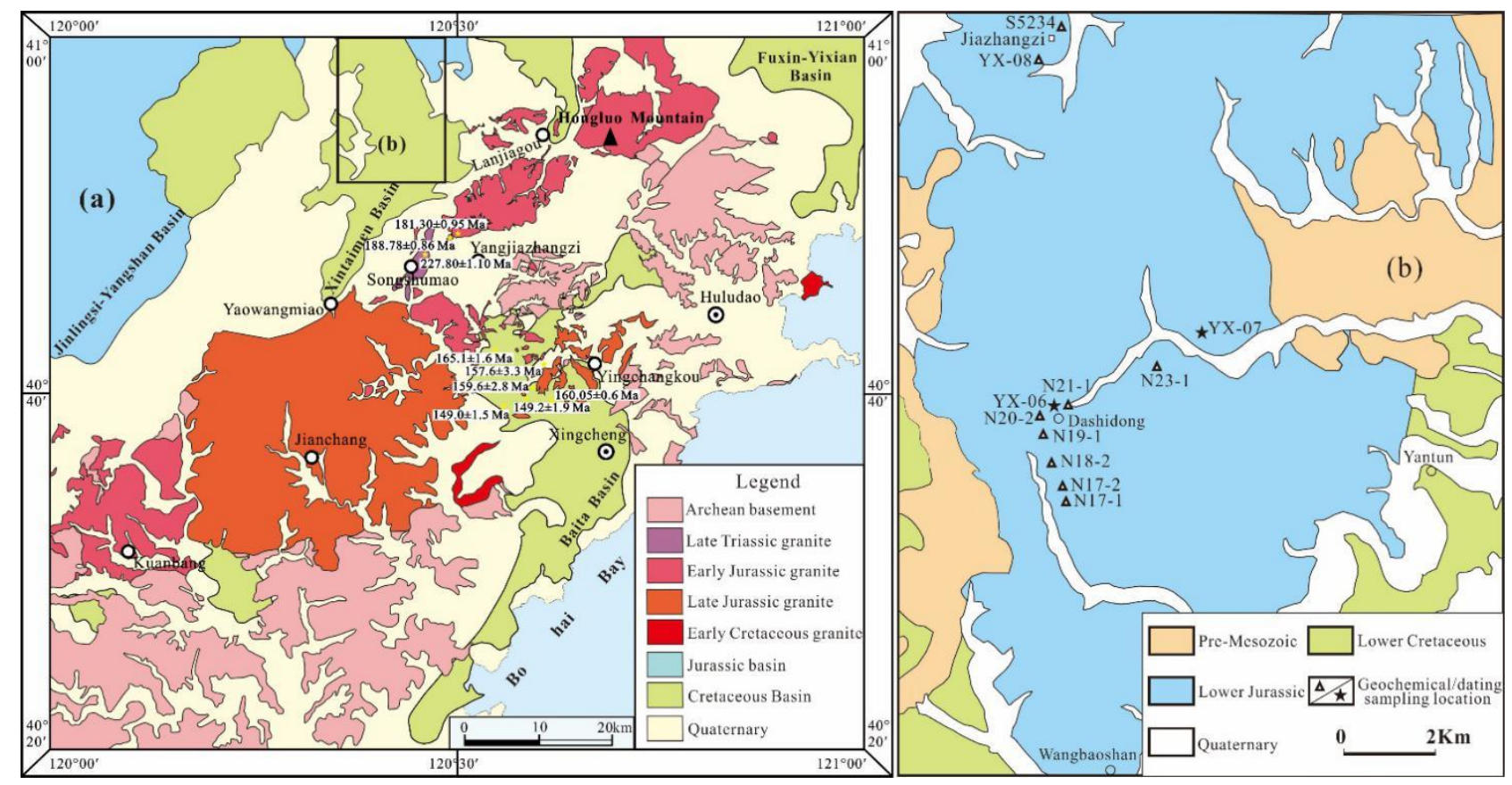

Figure 2. Geological map of Western Liaoning province (a); modified after Lin [52]) and distribution of Early Jurassic volcanic rocks with sampling locations $(\mathbf{b})$. Note: The rectangle $(\mathbf{b})$ in Figure $2 \mathrm{a}$ shows the location of Figure $2 \mathrm{~b}$. Figure $2 \mathrm{a}$ shows a traditional understanding of the basin distribution, Figure $2 b$ shows the volcanic rocks based on new-age data. Therefore, the area displayed as green in Figure 2a becomes blue in Figure 2b.

\section{Geological Setting}

The northern boundary of NCC is the Central Asian Orogenic Belt, adjacent to the Siberian Craton, and its eastern edge is connected with the Pacific plate, and its southern boundary is the Qinling-Dabie-Sulu ultrahigh-pressure belt, adjacent to the South China Craton (Figure 1). From Late Paleozoic to Mesozoic, the Western Liaoning region in the east of NCC has experienced a complex superimposition of the subduction and closure of the Paleo-Asian Ocean, the Paleo-Pacific tectonic regime, and the Mongolia-Okhotsk tectonic regime, which resulted in the thinning of the lithosphere and the strong tectonic-magmaticmetallogenic-basin-forming activities. The Mesozoic era is considered to be the main period of destruction of the NCC, which is the active period of strong Yanshan tectonic movement and magmatic activities such as lithospheric thinning and destruction, plate subduction, intracontinental orogeny, regional uplifting, and extension $[18,22,41,53,54]$. Therefore, Mesozoic volcanic rocks are closely related to such geological issues as the Mesozoic tectonic transformation in eastern China, crustal delamination and thinning in 
eastern NCC, and the biota expansion, which directly affect geologists' understanding of the ages and background of different geological events. [6,41,55].

Volcanic rocks are well developed in Western Liaoning, mainly distributed in the Mesozoic Jinlingsi-Yangshan volcanic belt and Fuxin-Yixian basin belt $[33,34,56]$. The volcanic activities began in the Late Triassic and reached the peak in the Early Cretaceous. According to the residual strata of the present basin in the study area, the volcanic-sedimentary basins widely developed in Western Liaoning can be divided into Jurassic basin and Cretaceous basins, among which the Jurassic basin is the Jinlingsi-Yangshan basin, and the Cretaceous basin is more extensive, such as Xiaodeyingzi basin, Xintaimen basin, Sierbao-Baita basin, and so on (Figure 2a). The main strata developed are volcanic rocks of the Guajishan Formation and Yixian Formation which are distributed in a NE direction. With further research, it is gradually discovered that a large number of Jurassic volcanic-sedimentary strata develop in the original thought Cretaceous basin. The Xintaimen basin is located in the northwestern part of the Yangjiazhangzi magmatic-metallogenic belt (Figure 2a,b). The first ${ }^{40} \mathrm{Ar} /{ }^{39} \mathrm{Ar}$ dating results of the andesite and basaltic andesite exposed in the basin were from the late Early Cretaceous to the early Late Cretaceous (110.9-92.8 Ma) [46]. A large number of salamander fossils belonging to the Jehol biota were found in the lacustrine purple argillaceous siltstone interbedded with gray-green andesite [44,50], and the basin was classified as the Early Cretaceous basin. This study now reports that large-scale Early Jurassic volcanic rocks are distributed in the Xintaimen basin in the NNE direction, which rests angular discordant on the limestone of Early and Middle Proterozoic Wumishan Formation and the limestone strata of Early Paleozoic. The rock assemblages of the volcanic rocks are mainly intermediate-acidic volcanic rocks which are composed of trachyandesite, trachyte, trachydacite, and a small amount of rhyolite. The detailed determination of the analyzed volcanic rocks is of great significance for establishing the chronological framework, petrogenesis, and tectonic setting of Mesozoic volcanic rocks in the Western Liaoning region.

\section{Sample Descriptions}

The typical volcanic rocks were selected for systematic analysis, and the main samples were classified into two groups. Trachydacites with a light gray or light purple gray colors are the most widely distributed in the basin. They have a porphyritic texture, a massive structure, and a fluidal structure that can be seen locally. Phenocrysts account for 5-30\% (Figure 3a,b), are mainly composed of plagioclase, hornblende, and biotite. The plagioclase is euhedral or subhedral granular with a polysynthetic twin. Some plagioclases have the characteristics of multiple crystallization, and the centers of some plagioclases have been altered. The hornblende is euhedral granular with black, some of which are directional. The matrix is a mikropoikilitic texture composed of irregular quartz inlaid with fine feldspar microcrystals (Figure 3c; YX-06).

Rhyolites are less exposed and mainly distributed in the trachyandesite interlayer. The weathered surface of the rocks is earth yellow, and the fresh surface is grayish-white or light yellow. It has a porphyritic and massive structure, and the phenocryst content is about $15-25 \%$. The porphyritic minerals are mainly composed of plagioclase, hornblende, quartz, and a small amount of biotite. The plagioclase is euhedral granular with a slight alteration, and part of the plagioclase presents a polysynthetic twin. The hornblende is euhedral granular with dark green. Quartz is xenomorphic granular and biotite is a brown flake. The matrix is mainly a fluidal structure composed of quartz and feldspar and other microcrystalline minerals (Figure 3d; YX-07). 

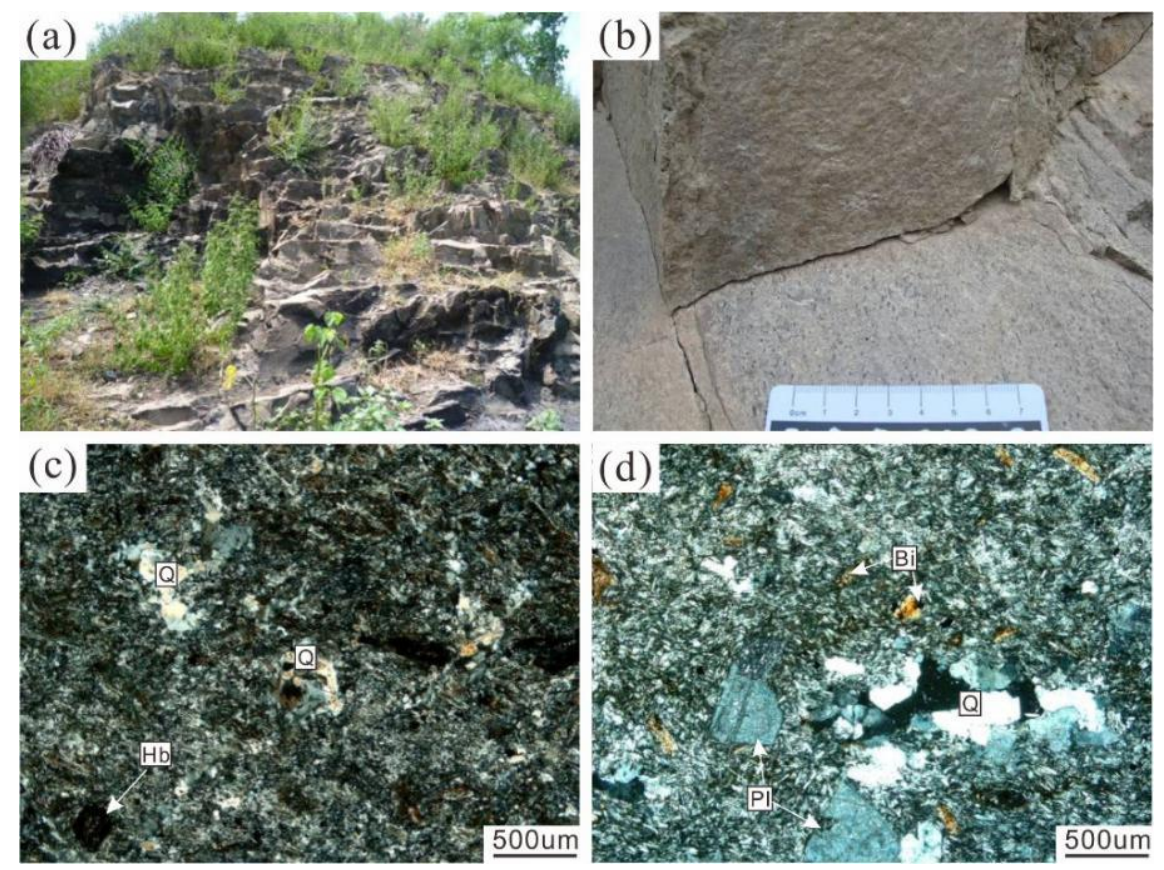

Figure 3. Representative meso- and micro-fabrics of Early Jurassic volcanic rocks. (a) Field outcrops of trachyticdacite. (b) Field outcrop of hornblende trachydacite (hornblende directional arrangement). (c) Trachyte amphibolite dacite (YX-06). (d) Rhyolite (YX-07). Note: Bi-Biotite; Hb-Hornblende; Pl-Plagioclase; Q-Quartz.

\section{Analytical Methods \\ 4.1. Zircon $U$-Pb Dating}

The trachydacite (YX-06) and rhyolite (YX-07) were selected for zircon $\mathrm{U}-\mathrm{Pb}$ isotopic dating. The sorting of zircon single mineral was completed in Langfang Regional Geological Survey, Hebei Province, China. The sample target was prepared and handmade in Beijing GeoAnaly/i/Co., Ltd., Beijing, China. LA-ICP-MS U-Pb zircon dating was carried out at the Key Laboratory of Mineral Resources Evaluation in Northeast Asia, Ministry of Natural Resources, Jilin University, Changchun, Jilin, China, using an ArF excimer laser system (GeoLas Pro, $193 \mathrm{~nm}$ wavelength) and a quadrupole ICP-MS (Agilent 7500a, Santa Clara, CA, USA). Some zircons have multiple zoning, however, we choose potential target sites carefully and ensured the reliability of our data which avoided a single analysis spot crossing multiple zones. Details of the analytical methods are given by Liang et al. [57]. The software Glitter was used to calculate the isotope ratio and element content. The data calculation and image rendering were processed using the ISOPLOT program (Version 3.23) [58]. Common Pb was corrected for following Andersen [59]. Uncertainties on individual analyses were reported with $1 \sigma$ error and weighted mean ages were calculated at $1 \sigma$ confidence level, representing the $95 \%$ confidence interval. The filtering of the $\mathrm{U}-\mathrm{Pb}$ ages was based on a $10 \%$ cut-off of the calculated discordance $(\% \mathrm{U}-\mathrm{Pb}$ disc $=$ $\left[1-\left({ }^{206} \mathrm{~Pb} /{ }^{238} \mathrm{U}\right.\right.$ age $/{ }^{207} \mathrm{~Pb} /{ }^{235} \mathrm{U}$ age $\left.\left.)\right] \times 100\right)$. The ${ }^{206} \mathrm{~Pb} /{ }^{207} \mathrm{~Pb}$ age for zircons with ages greater than $1000 \mathrm{Ma}$ was used, instead, for grains younger than $1000 \mathrm{Ma}$, the ${ }^{206} \mathrm{~Pb} /{ }^{238} \mathrm{U}$ age was used as the best age independence of the imprecise measurement of ${ }^{207} \mathrm{~Pb}$ in young grains.

\subsection{Major-and Trace-Element Analyses}

The pre-processing and analysis of the whole-rock samples were completed in the Test Center of No.1 Bureau of China Metallurgical Geology Bureau, Hebei Province, China. The major elements were analyzed by an X-ray fluorescence spectrometer (XRF, Japan Rigaku), and the testing instrument was a sequential $\mathrm{X}$-ray fluorescence spectrometer (AXIOS Minerals). Trace elements were tested by an inductively coupled plasma mass 
spectrometer (ICP-MS Agilent 7500ce). Details of the analytical methods are given by Hu et al. [60].

\subsection{Zircon Lu-Hf Isotope Analyses}

Based on the LA-ICP-MS U-Pb zircon dating, the in situ zircon Hf isotopic analysis of Mesozoic volcanic rocks in the Xintaimeng basin was carried out. The analysis was conducted using a Neptune Plus MC-ICP-MS (Thermo Fisher Scientific, Darmstadt, Germany) in combination with a Geolas 2005 excimer ArF laser ablation system $(193 \mathrm{~nm})$ that was hosted at the Solid Isotope Laboratory of Institute of Geology and Geophysics, Chinese Academy of Sciences, Beijing, China. The analysis spots were $44 \mu \mathrm{m}$ in diameter, and each measurement consisted of the $20 \mathrm{~s}$ of acquisition of the background signal followed by $50 \mathrm{~s}$ of acquisition of the ablation signal. The international standard sample 91,500 of zircon was used as the external standard for the measurement. The laser ablation rate was $8 \mathrm{~Hz}$ and the energy was $90 \mathrm{~mJ}$. Offline processing of analysis data (including the selection of samples and blank signals, and isotope mass fractionation correction) was completed by ICPMSDataCal software. Details of the analytical techniques are given by Hu et al. [61].

\section{Analytical Results}

\subsection{Zircon U-Pb Ages}

Zircons from trachydacite YX-06 (N: $40^{\circ} 55^{\prime} 25^{\prime \prime}, \mathrm{E}: 120^{\circ} 24^{\prime} 46^{\prime \prime}$ ) and rhyolite YX-07 $\left(\mathrm{N}: 40^{\circ} 56^{\prime} 11^{\prime \prime}, \mathrm{E}: 120^{\circ} 26^{\prime} 50^{\prime \prime}\right)$ are both euhedral-subhedral, with grain sizes ranging from 150-300 $\mu \mathrm{m}$ (Figure 4a,b). The elongation (length to width) ratios of zircons range from 1.5:1 to $2.5: 1$, suggesting a faster crystallization velocity. The CL image shows that the zircons have a clear internal structure, complete crystal shape, and mostly long columnar form, with a typical oscillatory growth zoning. Most zircons have locally preserved xenocrystic cores, which occur as cores mantled by newly grown zircon (Figure 4a,b). The occurrence of xenocrystic zircon is a common feature of many igneous rocks [62]. In addition, these zircons show continuity between core and rim, having high $U$ contents (ranging from 101 to $6632 \mathrm{ppm}$ ) and Th/U ratios mostly between 0.26 and 3.19 (Table 1), indicating magmatic origin.
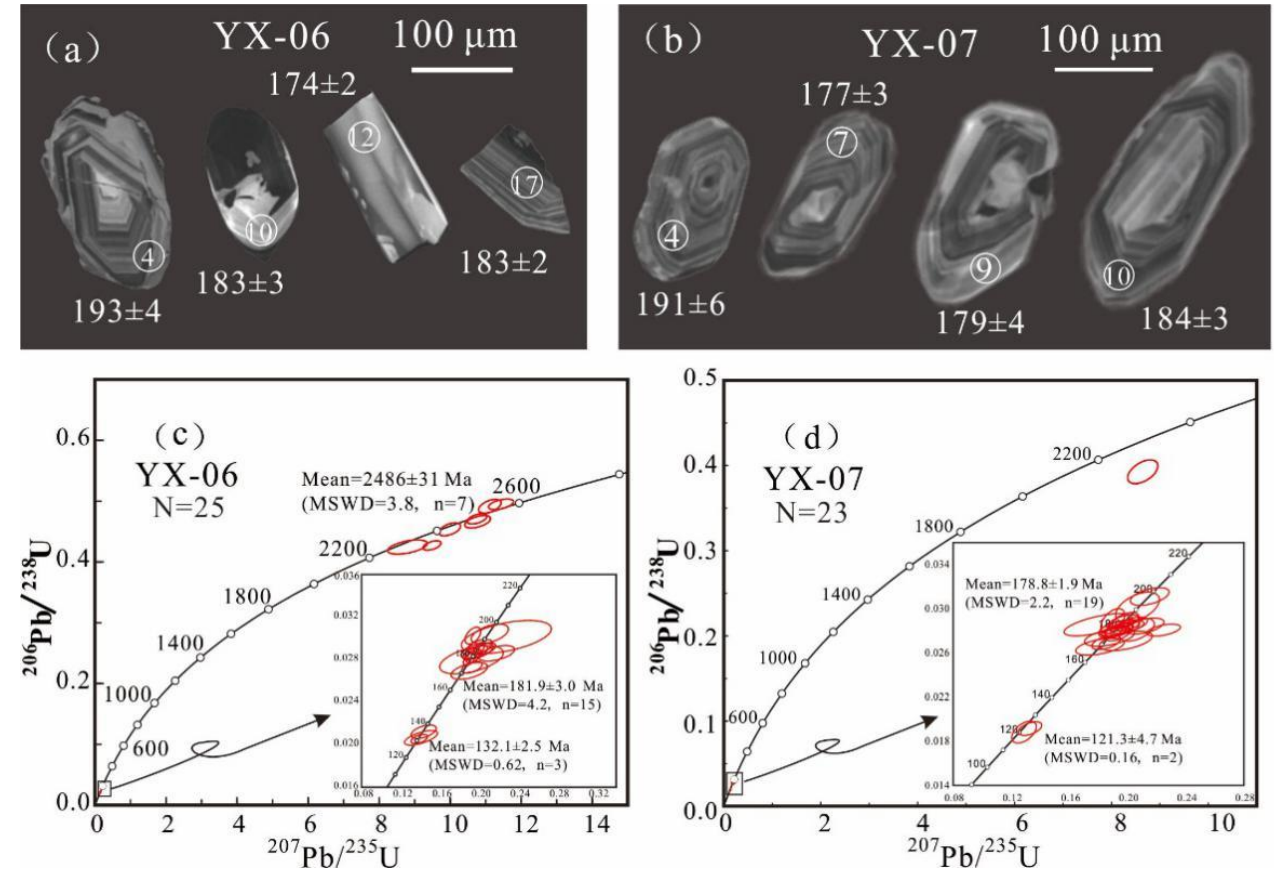

Figure 4. Cathodoluminescence images of representative zircons $(\mathbf{a}, \mathbf{b})$; Numbers on the images represent analysis spots, and the data near the images represent the associated ages) and ${ }^{206} \mathrm{~Pb} /{ }^{238} \mathrm{U}$ vs. ${ }^{207} \mathrm{~Pb} /{ }^{235} \mathrm{U}$ concordia plots of investigated samples (c,d). Errors are $1 \sigma$. 
Table 1. LA-ICP-MS zircon U-Pb dating results for the volcanic rocks in the Xintaimen Basin, Western Liaoning.

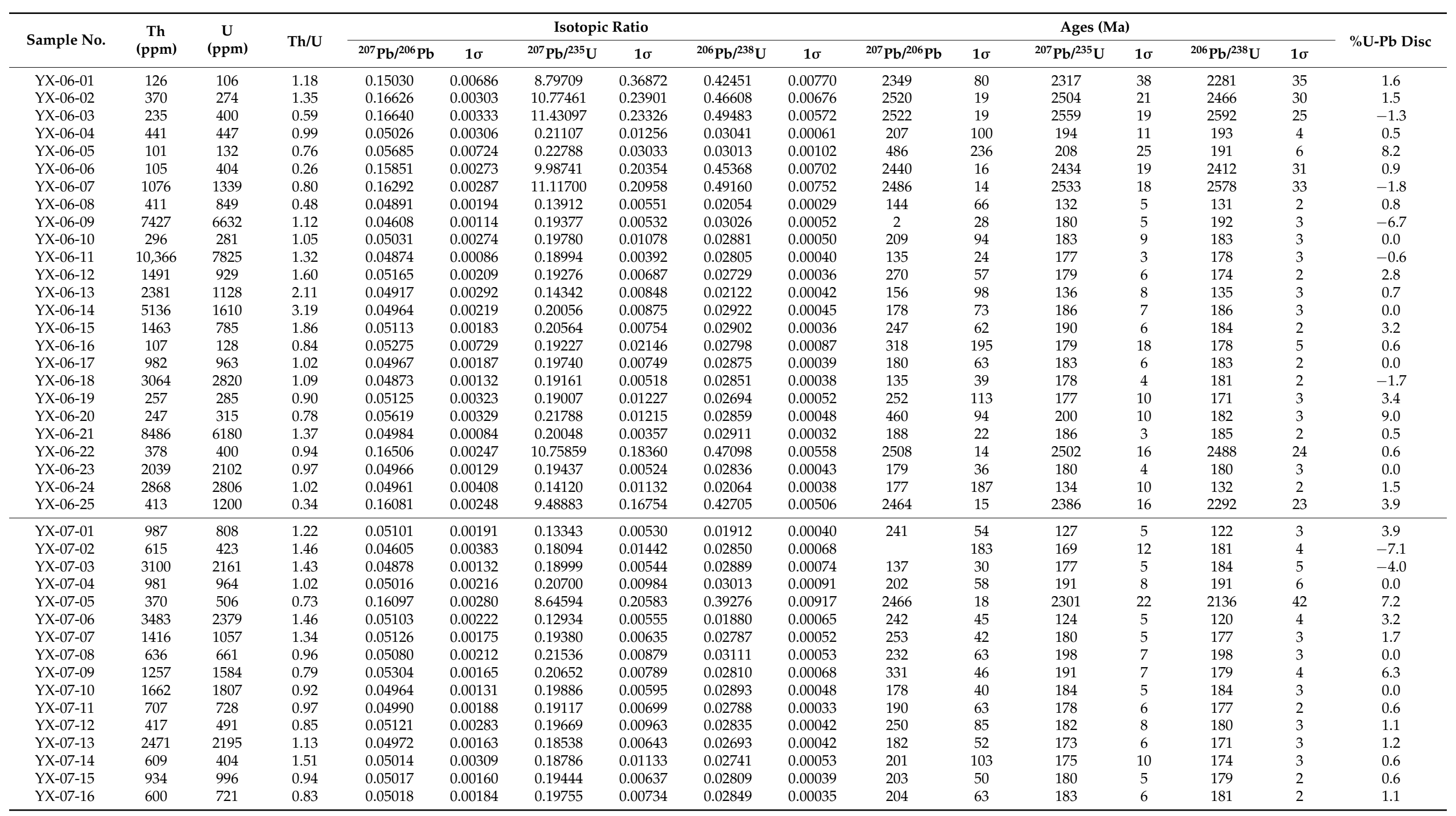


Table 1. Cont.

\begin{tabular}{|c|c|c|c|c|c|c|c|c|c|c|c|c|c|c|c|c|}
\hline \multirow{2}{*}{ Sample No. } & \multirow{2}{*}{$\begin{array}{c}\text { Th } \\
\text { (ppm) }\end{array}$} & \multirow{2}{*}{$\begin{array}{c}\mathrm{U} \\
(\mathrm{ppm})\end{array}$} & \multirow{2}{*}{$\mathrm{Th} / \mathrm{U}$} & \multicolumn{6}{|c|}{ Isotopic Ratio } & \multicolumn{6}{|c|}{ Ages (Ma) } & \multirow{2}{*}{ \%U-Pb Disc } \\
\hline & & & & ${ }^{207} \mathrm{~Pb} /{ }^{206} \mathrm{~Pb}$ & $1 \sigma$ & ${ }^{207} \mathrm{~Pb} /{ }^{235} \mathrm{U}$ & $1 \sigma$ & ${ }^{206} \mathrm{~Pb} /{ }^{238} \mathrm{U}$ & $1 \sigma$ & ${ }^{207} \mathrm{~Pb} /{ }^{206} \mathrm{~Pb}$ & $1 \sigma$ & ${ }^{207} \mathrm{~Pb} /{ }^{235} \mathrm{U}$ & $1 \sigma$ & ${ }^{206} \mathrm{~Pb} /{ }^{238} \mathrm{U}$ & $1 \sigma$ & \\
\hline YX-07-17 & 381 & 475 & 0.80 & 0.05468 & 0.00245 & 0.21181 & 0.00877 & 0.02842 & 0.00048 & 399 & 62 & 195 & 7 & 181 & 3 & 7.2 \\
\hline YX-07-18 & 614 & 784 & 0.78 & 0.05029 & 0.00171 & 0.19211 & 0.00627 & 0.02793 & 0.00036 & 209 & 51 & 178 & 5 & 178 & 2 & 0.0 \\
\hline YX-07-20 & 489 & 484 & 1.01 & 0.05388 & 0.00341 & 0.19902 & 0.01200 & 0.02707 & 0.00058 & 366 & 97 & 184 & 10 & 172 & 4 & 6.5 \\
\hline YX-07-21 & 485 & 1216 & 0.40 & 0.15184 & 0.00225 & 7.16232 & 0.12706 & 0.34103 & 0.00409 & 2367 & 15 & 2132 & 16 & 1892 & 20 & 11.3 \\
\hline YX-07-22 & 495 & 601 & 0.82 & 0.04966 & 0.00213 & 0.19455 & 0.00907 & 0.02822 & 0.00047 & 179 & 77 & 181 & 8 & 179 & 3 & 1.1 \\
\hline YX-07-23 & 1120 & 1359 & 0.82 & 0.05007 & 0.00184 & 0.19815 & 0.00676 & 0.02887 & 0.00037 & 198 & 55 & 184 & 6 & 183 & 2 & 0.5 \\
\hline YX-07-24 & 408 & 476 & 0.86 & 0.04980 & 0.00300 & 0.18128 & 0.01101 & 0.02655 & 0.00051 & 186 & 104 & 169 & 9 & 169 & 3 & 0.0 \\
\hline
\end{tabular}


A total of 25 zircons were analyzed in trachydacite YX-06, all of which were located near the concordia curve (Figure 4c). The weighted mean ${ }^{206} \mathrm{~Pb} /{ }^{238} \mathrm{U}$ age from the 15 zircon grains is $181.9 \pm 3.0 \mathrm{Ma}(\mathrm{MSWD}=4.2, n=15)$, which represents the timing of crystallization of this sample is late Early Jurassic. Seven zircon grains exhibit Paleoproterozoic ages, with a weighted mean ${ }^{206} \mathrm{~Pb} /{ }^{238} \mathrm{U}$ age of $2486 \pm 31 \mathrm{Ma}$ (MSWD $=3.8, n=7$ ), indicating inherited or captured zircons. The weighted mean ${ }^{206} \mathrm{~Pb} /{ }^{238} \mathrm{U}$ age from the two zircon grains is $132.1 \pm 2.5 \mathrm{Ma}$ (MSWD $=0.62, n=3$ ), which may be attributed to the later tectonic thermal events.

A total of 25 zircons tested from rhyolite YX-07 (Figure $4 \mathrm{~d}$ ) gave ${ }^{206} \mathrm{~Pb} /{ }^{238} \mathrm{U}$ ages of 19 zircons which ranged from 169 to $191 \mathrm{Ma}$, with a weighted mean ${ }^{206} \mathrm{~Pb} /{ }^{238} \mathrm{U}$ age of $178.8 \pm 1.9 \mathrm{Ma}(\mathrm{MSWD}=2.2, n=19)$, indicating the crystallization age of late Early Jurassic. The ${ }^{206} \mathrm{~Pb} /{ }^{238} \mathrm{U}$ ages of the 2 zircons are $198 \pm 3 \mathrm{Ma}$ and $2466 \pm 18 \mathrm{Ma}$, respectively, which may be the ages of the inherited zircons. The weighted mean ${ }^{206} \mathrm{~Pb} /{ }^{238} \mathrm{U}$ age from the two zircon grains is $121.3 \pm 4.7 \mathrm{Ma}$ (MSWD $=0.16, n=2$ ), indicating the late Early Cretaceous, which may represent the age of late tectonic thermal events. The two discordant ages probably are disturbed by $\mathrm{Pb}$ loss (\% $\mathrm{U}-\mathrm{Pb}$ disc $>10$, Table 1$)$, so they are inaccurate and are not used during our mapping.

\subsection{Geochemical Features}

\subsubsection{Major Elements}

Twelve typical fresh Early Jurassic intermediate-acidic volcanic rocks were selected for geochemical analysis, and the results are shown in Tables 2 and 3. The $\mathrm{SiO}_{2}$ in volcanic rocks is $60.70 \sim 71.45 \mathrm{wt} . \%$, which is a set of intermediate-acidic magmatic rocks. The volcanic rocks contain $\mathrm{Mg}^{\#}\left[\mathrm{Mg}^{\#}=100 \mathrm{Mg}^{2+} /\left(\mathrm{Mg}^{2+}+\mathrm{TFe}^{2+}\right)\right]$ values of $16-48,0.23-0.77$ wt. $\%$ $\mathrm{TiO}_{2}, 2.05-6.14$ wt.\% TFeO, 14.23-16.81 wt.\% $\mathrm{Al}_{2} \mathrm{O}_{3}, 0.63-4.21$ wt.\% $\mathrm{CaO}, 3.46-6.01$ wt.\% $\mathrm{Na}_{2} \mathrm{O}, 3.35-5.85$ wt.\% $\mathrm{K}_{2} \mathrm{O}, 0.79-1.79 \mathrm{Na}_{2} \mathrm{O} / \mathrm{K}_{2} \mathrm{O}$, and $\left(\mathrm{Na}_{2} \mathrm{O}+\mathrm{K}_{2} \mathrm{O}\right)$ concentrations of 7.79-11.28 wt.\% (Table 2). In the total-alkali vs. silica (TAS) diagram (Figure 5a), they fall into trachyte and rhyolite areas respectively (the normative Quartz more than $20 \mathrm{wt} . \%$ in most samples). In the $\mathrm{SiO}_{2}$ vs. $\mathrm{K}_{2} \mathrm{O}$ diagram (Figure $5 \mathrm{~b}$ ), the samples mainly fall into the area of high-K calc-alkaline series, and a small amount falls into the area of the shoshonite series. They have A/CNK values of $0.99-1.09$, indicating they are metaluminous to weakly peraluminous (Figure 5 c).
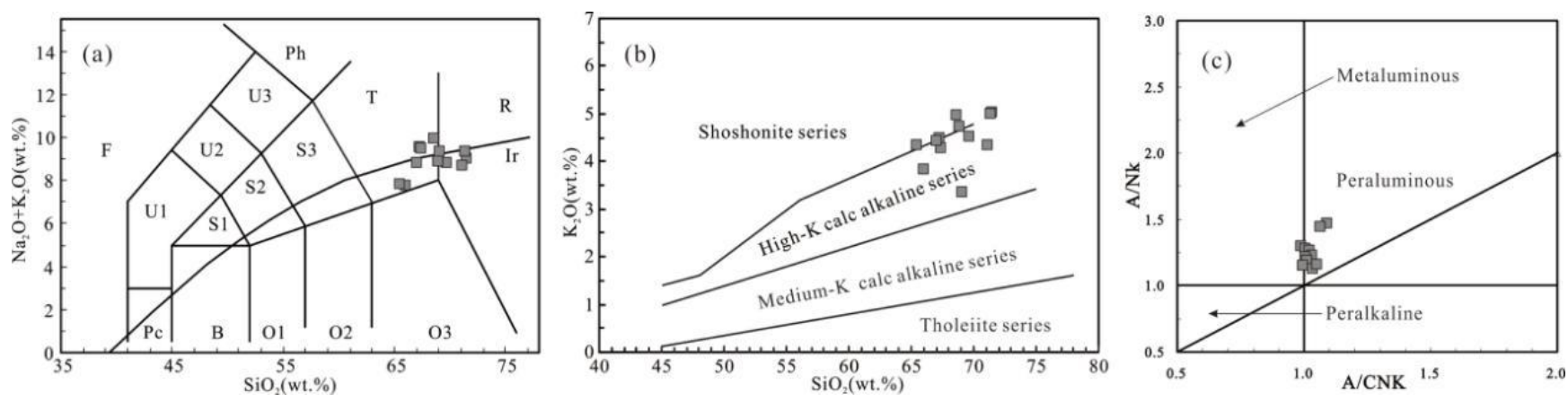

Figure 5. Total-alkali $\left(\mathrm{K}_{2} \mathrm{O}+\mathrm{Na}_{2} \mathrm{O}\right)$ vs. $\mathrm{SiO}_{2}$ (TAS) diagram (a), after Irvine and Baragar [63]), $\mathrm{SiO}_{2}$ vs. $\mathrm{K}_{2} \mathrm{O}$ diagram (b), after Peccerillo and Taylor [64]) and $\mathrm{Al}_{2} \mathrm{O}_{3} /\left(\mathrm{CaO}+\mathrm{Na}_{2} \mathrm{O}+\mathrm{K}_{2} \mathrm{O}\right)(\mathrm{A} / \mathrm{CNK})$ vs. $\mathrm{Al}_{2} \mathrm{O}_{3} /\left(\mathrm{Na}_{2} \mathrm{O}+\mathrm{K}_{2} \mathrm{O}\right)(\mathrm{ANK})$ diagram (c), after Maniar and Piccoli [65]) diagrams of the Early Jurassic volcanic rocks. F = Foidite; U1 = Tephrite/Basanite; U2 = Phonotephrite; U3 = Tephriphonolite; S1 = Trachybasalt; S2 = Basaltic trachyandesite; S3 = Trachyandesite; $\mathrm{T}=$ Trachyte $/$ Trachydacite Pc = Picrobasal $\mathrm{B}=$ Basalt $\mathrm{O} 1=$ Basaltic andesite $; \mathrm{O} 2$ = Andesite; $\mathrm{O} 3=$ Bacite; $\mathrm{R}=\mathrm{Rhyolite}$. 
Table 2. Major elements (wt.\%) compositions for the Early Jurassic volcanic rocks.

\begin{tabular}{|c|c|c|c|c|c|c|c|c|c|c|c|c|c|c|c|c|c|}
\hline $\begin{array}{c}\text { Sample } \\
\text { No. }\end{array}$ & Lithology & $\mathrm{SiO}_{2}$ & $\mathrm{TiO}_{2}$ & $\mathrm{Al}_{2} \mathrm{O}_{3}$ & $\mathrm{TFeO}$ & $\mathrm{MnO}$ & $\mathrm{MgO}$ & $\mathrm{CaO}$ & $\mathrm{Na}_{2} \mathrm{O}$ & $\mathrm{K}_{2} \mathrm{O}$ & $\mathrm{P}_{2} \mathrm{O}_{5}$ & LOI & Total & $\mathbf{M g}^{\#}$ & $\begin{array}{c}\mathrm{Na}_{2} \mathrm{O} \\
+ \\
\mathrm{K}_{2} \mathrm{O}\end{array}$ & $\mathrm{A} / \mathrm{CNK}$ & A/NK \\
\hline N17-1 & Trachydacite & 68.59 & 0.37 & 15.48 & 2.69 & 0.03 & 0.51 & 0.76 & 5 & 4.96 & 0.15 & 1.46 & 100.29 & 25.3 & 9.96 & 1.03 & 1.14 \\
\hline $\mathrm{N} 17-2$ & Trachydacite & 69.67 & 0.36 & 15.51 & 2.49 & 0.04 & 0.27 & 2.07 & 4.28 & 4.53 & 0.16 & 0.82 & 100.45 & 16.1 & 8.81 & 0.99 & 1.30 \\
\hline $\mathrm{N} 18-2$ & Trachydacite & 67.28 & 0.38 & 16.24 & 2.71 & 0.04 & 0.49 & 1.41 & 5.07 & 4.5 & 0.16 & 1.7 & 100.27 & 24.2 & 9.57 & 1.03 & 1.23 \\
\hline N19-1 & Trachydacite & 67.44 & 0.37 & 16.06 & 2.6 & 0.04 & 0.41 & 1.54 & 5.22 & 4.27 & 0.16 & 1.86 & 100.24 & 21.8 & 9.49 & 1.00 & 1.22 \\
\hline N20-2 & Trachydacite & 69.05 & 0.34 & 15.59 & 2.54 & 0.03 & 0.3 & 1.19 & 6.01 & 3.35 & 0.16 & 1.38 & 100.22 & 17.2 & 9.36 & 0.99 & 1.15 \\
\hline N21-1 & Trachydacite & 66 & 0.52 & 15.39 & 4.51 & 0.07 & 1.78 & 2.11 & 3.95 & 3.82 & 0.3 & 2.42 & 101.37 & 41.3 & 7.77 & 1.06 & 1.45 \\
\hline N22-1 & Trachydacite & 67.05 & 0.36 & 15.34 & 2.88 & 0.05 & 0.55 & 1.84 & 4.35 & 4.43 & 0.17 & 2.96 & 100.29 & 25.5 & 8.78 & 1.00 & 1.28 \\
\hline N23-1 & Rhyolite & 71.45 & 0.28 & 14.23 & 2.69 & 0.03 & 0.57 & 1.17 & 3.97 & 5.02 & 0.11 & 1.02 & 100.84 & 27.4 & 8.99 & 1.01 & 1.19 \\
\hline YX-06 & Trachydacite & 65.47 & 0.41 & 15.29 & 3.38 & 0.08 & 1.66 & 2 & 3.46 & 4.34 & 0.19 & 3.9 & 100.54 & 46.7 & 7.8 & 1.09 & 1.47 \\
\hline YX-07 & Rhyolite & 71.39 & 0.28 & 14.41 & 2.44 & 0.06 & 0.4 & 0.63 & 4.35 & 5 & 0.1 & 1.26 & 100.58 & 22.5 & 9.35 & 1.05 & 1.15 \\
\hline YX-08 & Trachydacite & 68.9 & 0.24 & 15.16 & 2.43 & 0.2 & 0.65 & 1.61 & 4.15 & 4.73 & 0.09 & 2.12 & 100.56 & 32.4 & 8.88 & 1.02 & 1.27 \\
\hline S5234 & Rhyolite & 71.13 & 0.23 & 14.93 & 2.05 & 0.06 & 0.42 & 1.62 & 4.34 & 4.35 & 0.08 & 0.8 & 100.23 & 26.7 & 8.69 & 1.01 & 1.26 \\
\hline
\end{tabular}

Table 3. Trace elements for the Early Jurassic volcanic rocks.

\begin{tabular}{|c|c|c|c|c|c|c|c|c|c|c|c|c|}
\hline $\begin{array}{c}\text { Sample } \\
\text { No. }\end{array}$ & N17-1 & N17-2 & N18-2 & N19-1 & N20-2 & N21-1 & N22-1 & N23-1 & YX-06 & YX-07 & YX-08 & S5234 \\
\hline $\mathrm{Cr}$ & 9.05 & 6.95 & 5.66 & 5.84 & 6.47 & 10.9 & 13.2 & 6.76 & 26.5 & 11.5 & 6.90 & 8.49 \\
\hline $\mathrm{Ni}$ & 2.03 & 2.58 & 2.21 & 2.39 & 3.90 & 9.34 & 6.31 & 3.91 & 15.4 & 4.34 & 2.23 & 2.82 \\
\hline $\mathrm{Sc}$ & 1.92 & 2.54 & 2.34 & 2.23 & 2.63 & 4.42 & 3.00 & 2.72 & 4.17 & 2.61 & 3.01 & 2.34 \\
\hline Co & 3.55 & 2.84 & 3.89 & 3.66 & 3.66 & 7.54 & 4.96 & 3.42 & 6.95 & 3.58 & 3.29 & 2.83 \\
\hline $\mathrm{V}$ & 34.8 & 36.1 & 32.4 & 35.0 & 30.5 & 50.3 & 36.1 & 28.9 & 45.9 & 23.3 & 20.8 & 24.8 \\
\hline $\mathrm{Ba}$ & 1459 & 1529 & 1565 & 1402 & 926 & 1451 & 1330 & 1299 & 1493 & 907 & 915 & 947 \\
\hline $\mathrm{Rb}$ & 119 & 113 & 115 & 109 & 76.4 & 95.8 & 119 & 150 & 113 & 133 & 93.4 & 88.4 \\
\hline Th & 3.29 & 4.57 & 4.44 & 4.03 & 3.92 & 4.80 & 4.00 & 10.5 & 4.59 & 7.83 & 3.23 & 2.92 \\
\hline $\mathrm{U}$ & 0.89 & 1.45 & 1.10 & 1.11 & 1.09 & 1.37 & 1.19 & 1.77 & 1.12 & 1.70 & 0.58 & 0.81 \\
\hline $\mathrm{Nb}$ & 12.5 & 11.9 & 12.2 & 12.5 & 15.3 & 14.0 & 13.3 & 10.4 & 12.6 & 10.4 & 9.75 & 9.05 \\
\hline $\mathrm{Ta}$ & 0.93 & 1.01 & 1.01 & 1.00 & 1.13 & 1.08 & 1.10 & 1.06 & 0.97 & 0.83 & 0.62 & 0.76 \\
\hline $\mathrm{Sr}$ & 541 & 748 & 800 & 865 & 458 & 632 & 695 & 453 & 565 & 156 & 340 & 395 \\
\hline $\mathrm{Zr}$ & 157 & 152 & 157 & 155 & 150 & 153 & 153 & 165 & 152 & 165 & 120 & 113 \\
\hline $\mathrm{Hf}$ & 8.02 & 7.26 & 7.05 & 6.54 & 6.90 & 6.74 & 6.30 & 5.50 & 6.14 & 4.75 & 6.42 & 4.17 \\
\hline $\mathrm{Y}$ & 5.7 & 6.0 & 6.8 & 7.2 & 7.5 & 7.2 & 7.3 & 6.4 & 7.4 & 6.0 & 6.81 & 5.95 \\
\hline $\mathrm{Pb}$ & 15.6 & 17.8 & 18.8 & 17.8 & 18.7 & 19.7 & 17.5 & 24.6 & 18.1 & 19.7 & 17.0 & 18.0 \\
\hline $\mathrm{Ga}$ & 15.2 & 17.8 & 18.4 & 17.5 & 18.6 & 18.8 & 15.6 & 16.3 & 18.6 & 13.3 & 16.3 & 16.2 \\
\hline Cs & 1.08 & 1.71 & 1.44 & 1.22 & 0.96 & 1.14 & 1.36 & 1.95 & 2.72 & 0.90 & 0.47 & 0.67 \\
\hline $\mathrm{La}$ & 13.62 & 25.31 & 31.46 & 31.37 & 31.00 & 33.33 & 18.19 & 32.12 & 24.15 & 29.54 & 20.20 & 17.58 \\
\hline $\mathrm{Ce}$ & 36.67 & 54.05 & 59.75 & 64.10 & 61.85 & 66.30 & 47.18 & 68.40 & 56.42 & 61.98 & 43.21 & 40.87 \\
\hline $\operatorname{Pr}$ & 4.95 & 6.17 & 7.10 & 7.17 & 6.85 & 8.11 & 6.11 & 7.46 & 6.64 & 6.37 & 5.43 & 4.85 \\
\hline $\mathrm{Nd}$ & 17.87 & 20.38 & 23.03 & 23.29 & 22.11 & 26.94 & 21.51 & 22.69 & 22.46 & 19.42 & 17.90 & 16.30 \\
\hline $\mathrm{Sm}$ & 2.92 & 3.25 & 3.32 & 3.40 & 3.44 & 4.15 & 3.64 & 3.52 & 3.67 & 2.91 & 2.67 & 2.52 \\
\hline $\mathrm{Eu}$ & 0.84 & 0.95 & 1.04 & 1.05 & 0.93 & 1.29 & 1.01 & 0.83 & 1.12 & 0.65 & 0.81 & 0.67 \\
\hline $\mathrm{Gd}$ & 2.47 & 2.77 & 3.01 & 3.01 & 2.98 & 3.52 & 2.90 & 2.61 & 2.88 & 2.52 & 2.46 & 2.29 \\
\hline $\mathrm{Tb}$ & 0.29 & 0.30 & 0.32 & 0.35 & 0.35 & 0.38 & 0.34 & 0.32 & 0.34 & 0.27 & 0.29 & 0.26 \\
\hline Dy & 1.31 & 1.33 & 1.46 & 1.53 & 1.61 & 1.69 & 1.63 & 1.40 & 1.62 & 1.23 & 1.37 & 1.20 \\
\hline Ho & 0.22 & 0.22 & 0.26 & 0.25 & 0.27 & 0.28 & 0.27 & 0.25 & 0.28 & 0.23 & 0.25 & 0.20 \\
\hline $\mathrm{Er}$ & 0.58 & 0.64 & 0.68 & 0.77 & 0.79 & 0.79 & 0.78 & 0.67 & 0.81 & 0.64 & 0.69 & 0.64 \\
\hline $\mathrm{Tm}$ & 0.09 & 0.10 & 0.10 & 0.10 & 0.12 & 0.11 & 0.11 & 0.11 & 0.11 & 0.09 & 0.11 & 0.10 \\
\hline $\mathrm{Yb}$ & 0.55 & 0.65 & 0.65 & 0.70 & 0.75 & 0.70 & 0.73 & 0.66 & 0.71 & 0.60 & 0.72 & 0.62 \\
\hline $\mathrm{Lu}$ & 0.09 & 0.10 & 0.09 & 0.11 & 0.11 & 0.10 & 0.11 & 0.10 & 0.10 & 0.09 & 0.11 & 0.10 \\
\hline $\mathrm{Eu}^{*}$ & 0.93 & 0.95 & 0.99 & 0.99 & 0.87 & 1.01 & 0.92 & 0.80 & 1.02 & 0.71 & 0.95 & 0.84 \\
\hline $\mathrm{Sr} / \mathrm{Y}$ & 94.28 & 123.59 & 117.94 & 120.28 & 60.82 & 87.49 & 94.91 & 70.81 & 76.24 & 25.80 & 49.86 & 66.48 \\
\hline$\Sigma \mathrm{REE}$ & 82 & 116 & 132 & 137 & 133 & 148 & 105 & 141 & 121 & 127 & 96 & 88 \\
\hline$(\mathrm{La} / \mathrm{Yb})_{\mathrm{N}}$ & 16.70 & 26.40 & 32.55 & 30.37 & 27.97 & 32.27 & 16.74 & 32.79 & 22.89 & 33.10 & 18.98 & 19.25 \\
\hline $\mathrm{Nb} / \mathrm{Ta}$ & 13.52 & 11.77 & 12.05 & 12.55 & 13.56 & 12.96 & 12.15 & 9.78 & 13.04 & 12.55 & 15.71 & 11.93 \\
\hline$(\mathrm{Gd} / \mathrm{Yb})_{\mathrm{N}}$ & 3.63 & 3.46 & 3.73 & 3.49 & 3.21 & 4.08 & 3.19 & 3.19 & 3.27 & 3.38 & 2.77 & 3.00 \\
\hline $\mathrm{Ce} / \mathrm{Pb}$ & 2.35 & 3.04 & 3.19 & 3.60 & 3.31 & 3.37 & 2.69 & 2.78 & 3.12 & 3.15 & 2.54 & 2.27 \\
\hline $\mathrm{Nb} / \mathrm{U}$ & 14.16 & 8.25 & 11.11 & 11.28 & 14.03 & 10.22 & 11.26 & 5.85 & 11.29 & 6.10 & 16.73 & 11.22 \\
\hline
\end{tabular}

According to the Harker diagram (Figure 6), there is a negative correlation between the major elements and $\mathrm{SiO}_{2}$. These geochemical variations can be attributed to mineral fractional crystallization during magmatic evolution. $\mathrm{MgO}, \mathrm{TFeO}, \mathrm{CaO}$ have an approximately negative correlation with $\mathrm{SiO}_{2}$, which may indicate the fractional crystallization of clinopyroxene and hornblende. The decreases in $\mathrm{Al}_{2} \mathrm{O}_{3}$ and $\mathrm{Sr}$ concentrations with increasing $\mathrm{SiO}_{2}$ probably relate to the fractionation of plagioclase. In addition, the decrease in $\mathrm{TiO}_{2}$ 
with increasing $\mathrm{SiO}_{2}$ content can be attributed to fractional crystallization of titaniferous minerals such as rutile, ilmenite, and sphene. In summary, we propose that mineral fractional crystallization during magmatic evolution is responsible for compositional variations in these volcanic rocks.

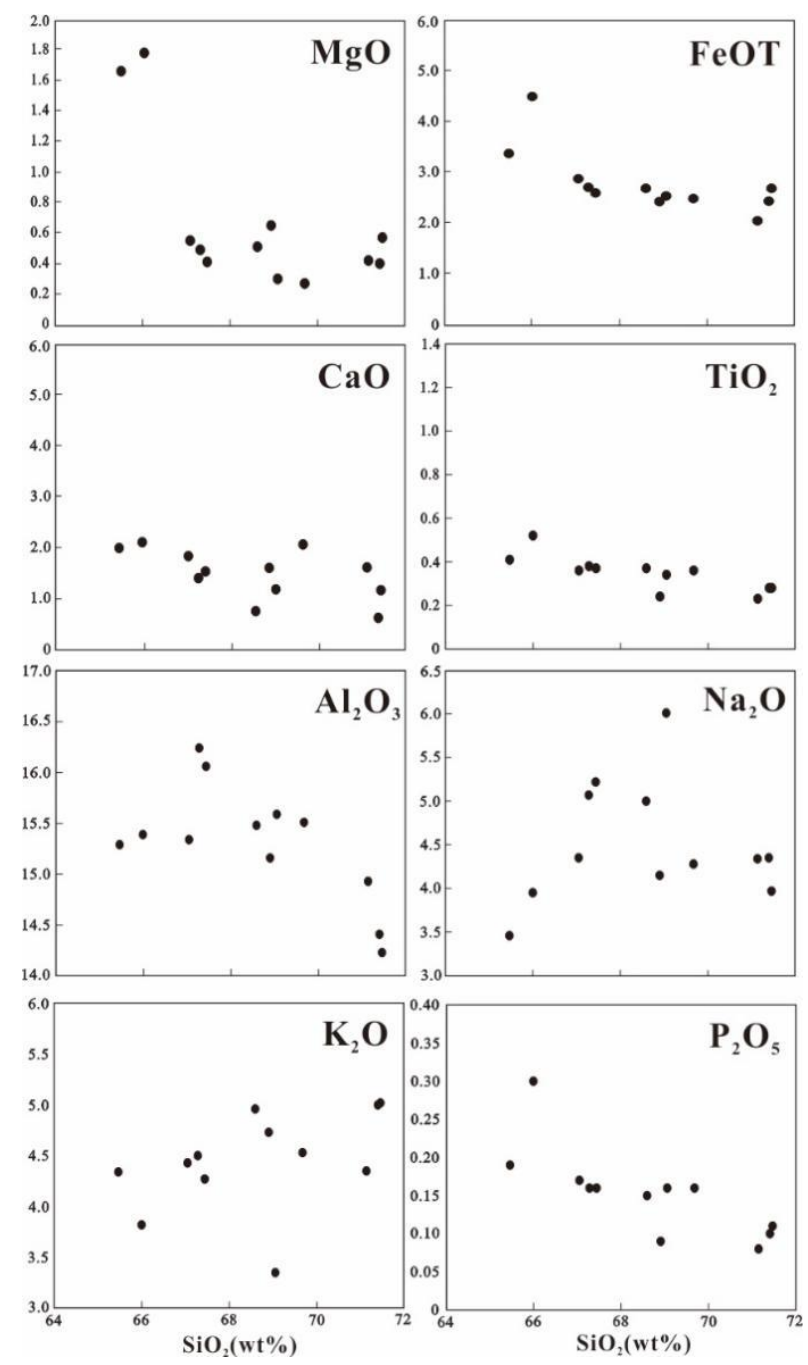

Figure 6. Variations of major elements vs. $\mathrm{SiO}_{2}$ diagrams (Harker diagrams) of the Early Jurassic volcanic rocks.

\subsubsection{Trace and Rare Earth Elements}

In the primitive mantle normalized trace element spidergrams (Figure 7a), the samples are relatively enriched in large ion lithophile elements (LILEs; e.g., $\mathrm{Ba}, \mathrm{Rb}, \mathrm{K}$, and $\mathrm{Sr}$ ), depleted in high field strength elements (HFSEs; e.g., $\mathrm{Nb}, \mathrm{Ta}$, $\mathrm{Ti}$, and $\mathrm{P}$ ), and have obvious geochemical characteristics of positive $\mathrm{Pb}$ anomalies. The samples are enriched in LILEs, $\mathrm{Pb}$, and HFSEs ( $\mathrm{Zr}$ and $\mathrm{Hf}$ ), in which $\mathrm{Ba}$ is more enriched than $\mathrm{Rb}$ and $\mathrm{Th}$, and HFSEs $(\mathrm{Nb}, \mathrm{Ta}$, and $\mathrm{Ti})$ are relatively depleted, indicating the characteristics of continental crust. The ratios of $\mathrm{Sr} / \mathrm{Y}$ and $\mathrm{Nb} / \mathrm{Ta}$ are high, and the contents of LILEs such as Sr (340-865 $\mu \mathrm{g} / \mathrm{g}$, except XY-07), Ba (907-1565 $\mu \mathrm{g} / \mathrm{g}), \mathrm{U}(0.58-1.77 \mu \mathrm{g} / \mathrm{g})$, and Th $(2.92-10.5 \mu \mathrm{g} / \mathrm{g})$ are high, which are similar to the geochemical characteristics of adakitic volcanic rocks. In the chondrite normalized REE patterns (Figure 7b), the samples are enriched in light rare earth elements (LREEs) and depleted in heavy rare earth elements (HREEs), showing an overall right-leaning curve as a whole, with obvious fractionation of light and heavy rare earth elements $\left((\mathrm{La} / \mathrm{Yb})_{\mathrm{N}}=16.70-38.71\right)$, as well as weak negative Eu anomalies $(\delta \mathrm{Eu}=0.7-1.04)$. The $\mathrm{Yb}$ content is less than $0.75 \mu \mathrm{g} / \mathrm{g}$, and the $\mathrm{Y}$ content 
is less than $7.5 \mu \mathrm{g} / \mathrm{g}$, which may imply that there are residual garnet and other minerals in the source area and the crystallization separation of the plagioclase is not obvious during the original magma evolution. The lower contents of the compatible elements Co $(2.83-7.54 \mu \mathrm{g} / \mathrm{g}), \mathrm{Ni}(2.03-15.4 \mu \mathrm{g} / \mathrm{g})$, and $\mathrm{Cr}(5.66-26.5 \mu \mathrm{g} / \mathrm{g})$ suggest that the magma may have originated from partial melting of crustal materials.
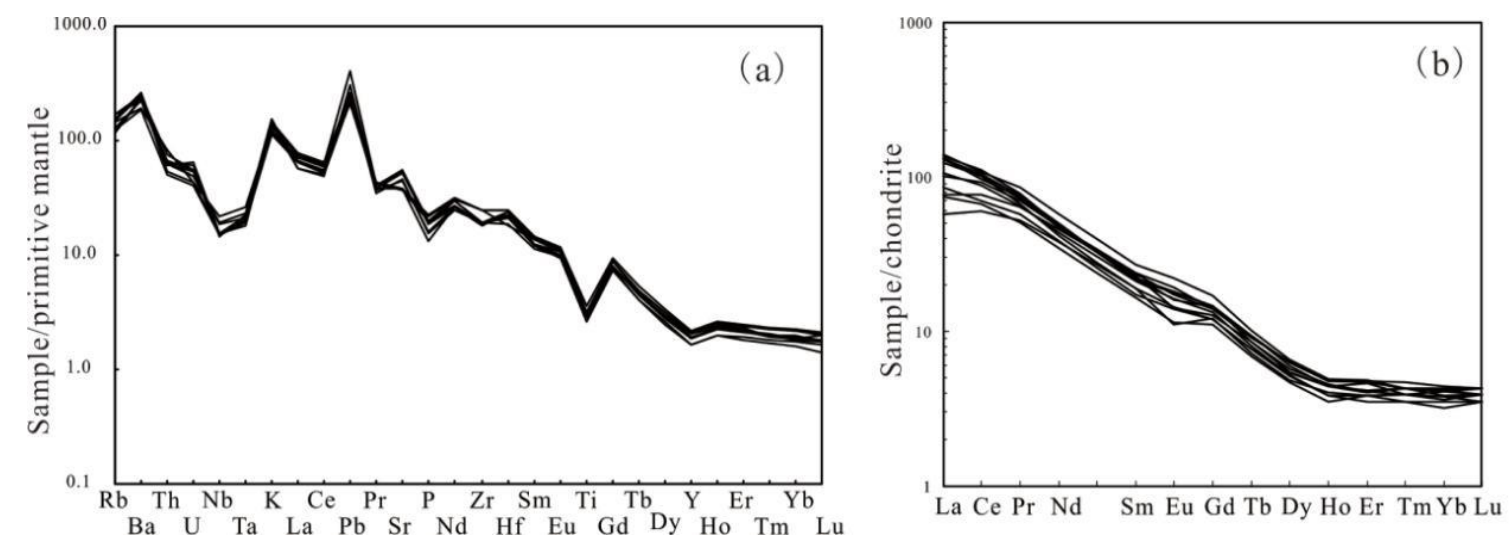

Figure 7. Primitive mantle normalized trace element spidergrams (a), after Sun and McDonough [66]) and chondrite normalized rare earth element (REE) patterns (b), after Boynton [67]) of the Early Jurassic volcanic rocks.

\subsection{Zircon Hf Isotopes}

On the basis of $\mathrm{U}-\mathrm{Pb}$ zircon dating, $\mathrm{Lu}-\mathrm{Hf}$ isotopic analysis of representative zircons was carried out, and the analysis results are shown in Table 4 . The results show that the ${ }^{176} \mathrm{Hf} /{ }^{177} \mathrm{Hf}$ ratios of the seven zircons with a crystallization age of about $181 \mathrm{Ma}$ in the sample YX-06 range from 0.282222 to 0.282339 . The corresponding $\varepsilon_{\mathrm{Hf}}(\mathrm{t})$ values range from -16.0 to -11.7 , and the two-stage model ages $\left(\mathrm{T}_{\mathrm{DM} 2}\right)$ range from 1961 to $2232 \mathrm{Ma}$, suggesting that the source area may be derived from the ancient lower crust of the Proterozoic (Table 4, Figure 8). It is worth noting that the $\sim 174 \mathrm{Ma}$ zircon have ${ }^{176} \mathrm{Hf} /{ }^{177} \mathrm{Hf}$ ratio of $0.282619, \varepsilon_{\mathrm{Hf}}(\mathrm{t})$ value of -2.3 , and the two-stage model age $\left(\mathrm{T}_{\mathrm{DM} 2}\right)$ of $1363 \mathrm{Ma}$, indicating that the magma source area may be contributed by depleted mantle material (Table 4, Figure 8). The ${ }^{176} \mathrm{Hf} /{ }^{177} \mathrm{Hf}$ ratios of the 13 zircons with a crystallization age of about 178Ma in the sample YX-07 range from 0.282337 to 0.282457 . The corresponding $\varepsilon_{\mathrm{Hf}}(\mathrm{t})$ values range from -11.6 to -7.4 , and the two-stage model ages $\left(\mathrm{T}_{\mathrm{DM} 2}\right)$ range from 1692 to $1958 \mathrm{Ma}$, which also suggests that the magma may be derived from the Proterozoic lower crust (Figure 8).
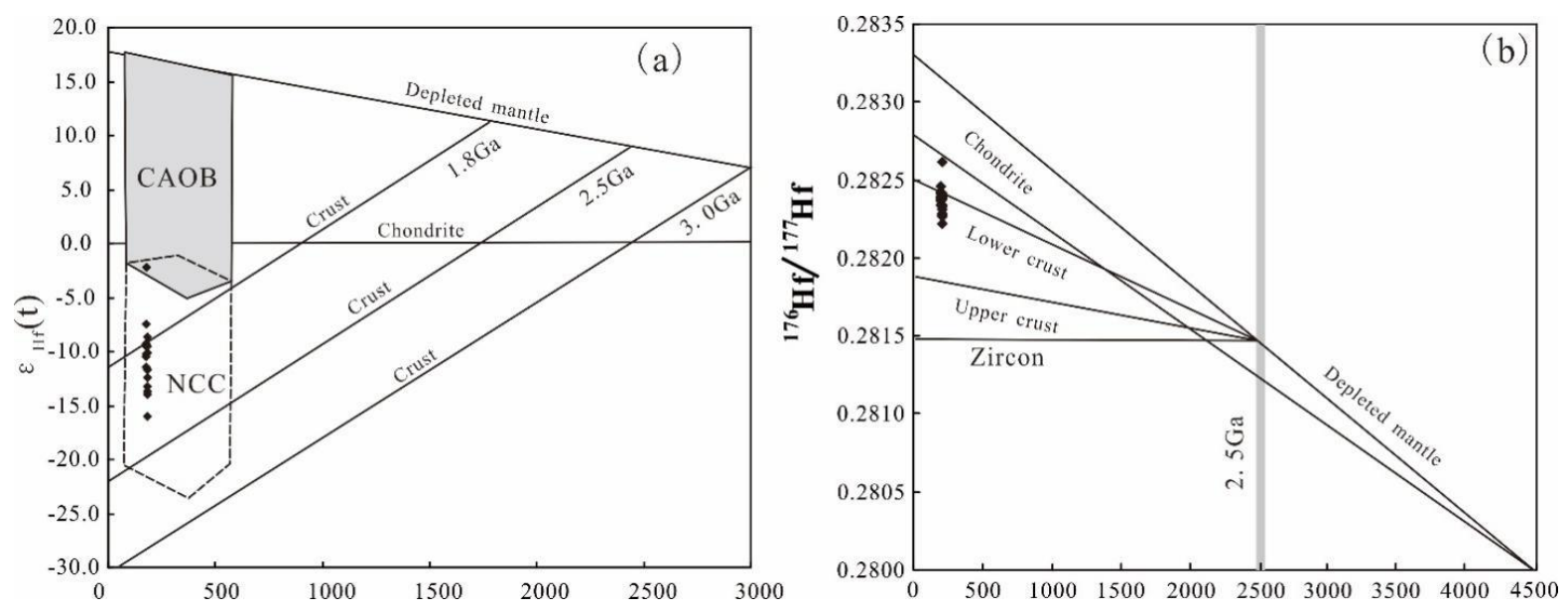

Figure 8. Zircon Hf isotopic characteristics of Early Jurassic volcanic rocks in the geological corridor of western Liaoning (a), after Yang et al. [68]; (b), after Wu et al. [69]). CAOB = Central Asian Orogenic Belt; NCC = North China Craton. 
Table 4. Zircon Hf isotopic data for the Early Jurassic volcanic rocks.

\begin{tabular}{|c|c|c|c|c|c|c|c|c|c|c|c|}
\hline Sample No. & t (Ma) & ${ }^{176} \mathrm{Yb} /{ }^{177} \mathrm{Hf}$ & ${ }^{176} \mathrm{Lu} /{ }^{177} \mathrm{Hf}$ & ${ }^{176} \mathrm{Hf} /{ }^{177} \mathrm{Hf}$ & $2 \sigma$ & $\varepsilon_{\mathrm{Hf}}(0)$ & $\varepsilon_{\mathrm{Hf}}(\mathrm{t})$ & $2 \sigma$ & $\mathrm{T}_{\mathrm{DM} 1}$ & $\mathrm{~T}_{\mathrm{DM} 2}$ & $\mathrm{f}_{\mathrm{Lu} / \mathrm{Hf}}$ \\
\hline YX-06 01 & 181 & 0.017562 & 0.000732 & 0.282267 & 0.000024 & -17.9 & -14.0 & 0.9 & 1381 & 2109 & -0.98 \\
\hline YX-06 02 & 174 & 0.159603 & 0.006290 & 0.282619 & 0.000029 & -5.4 & -2.3 & 1.0 & 1042 & 1363 & -0.81 \\
\hline YX-06 03 & 181 & 0.072934 & 0.002811 & 0.282339 & 0.000026 & -15.3 & -11.7 & 0.9 & 1353 & 1961 & -0.92 \\
\hline YX-06 04 & 181 & 0.036005 & 0.001416 & 0.282314 & 0.000022 & -16.2 & -12.4 & 0.8 & 1339 & 2008 & -0.96 \\
\hline YX-06 05 & 181 & 0.024457 & 0.000980 & 0.282333 & 0.000016 & -15.5 & -11.7 & 0.6 & 1297 & 1963 & -0.97 \\
\hline YX-06 06 & 181 & 0.013396 & 0.000554 & 0.282286 & 0.000020 & -17.2 & -13.3 & 0.7 & 1347 & 2063 & -0.98 \\
\hline YX-06 07 & 181 & 0.101319 & 0.004242 & 0.282222 & 0.000021 & -19.4 & -16.0 & 0.7 & 1588 & 2232 & -0.87 \\
\hline YX-06 08 & 181 & 0.040907 & 0.001688 & 0.282278 & 0.000016 & -17.5 & -13.7 & 0.6 & 1399 & 2090 & -0.95 \\
\hline YX-07 01 & 178 & 0.026983 & 0.001225 & 0.282337 & 0.000021 & -15.4 & -11.6 & 0.7 & 1300 & 1958 & -0.96 \\
\hline YX-07 02 & 178 & 0.018633 & 0.000788 & 0.282376 & 0.000020 & -14.0 & -10.2 & 0.7 & 1231 & 1868 & -0.98 \\
\hline YX-07 03 & 178 & 0.025697 & 0.001121 & 0.282368 & 0.000019 & -14.3 & -10.5 & 0.7 & 1252 & 1887 & -0.97 \\
\hline YX-07 04 & 178 & 0.021462 & 0.001011 & 0.282384 & 0.000020 & -13.7 & -9.9 & 0.7 & 1227 & 1851 & -0.97 \\
\hline YX-07 05 & 178 & 0.031338 & 0.001402 & 0.282397 & 0.000018 & -13.3 & -9.5 & 0.6 & 1221 & 1824 & -0.96 \\
\hline YX-07 06 & 178 & 0.041823 & 0.001694 & 0.282457 & 0.000025 & -11.1 & -7.4 & 0.9 & 1145 & 1692 & -0.95 \\
\hline YX-07 07 & 178 & 0.039303 & 0.001810 & 0.282378 & 0.000020 & -13.9 & -10.2 & 0.7 & 1261 & 1869 & -0.95 \\
\hline YX-07 08 & 178 & 0.017971 & 0.000770 & 0.282425 & 0.000016 & -12.3 & -8.5 & 0.6 & 1162 & 1758 & -0.98 \\
\hline YX-07 09 & 178 & 0.022984 & 0.001002 & 0.282416 & 0.000019 & -12.6 & -8.8 & 0.7 & 1181 & 1779 & -0.97 \\
\hline YX-07 10 & 178 & 0.032837 & 0.001463 & 0.282341 & 0.000021 & -15.2 & -11.5 & 0.8 & 1301 & 1949 & -0.96 \\
\hline YX-07 11 & 178 & 0.027010 & 0.001296 & 0.282408 & 0.000017 & -12.9 & -9.1 & 0.6 & 1202 & 1799 & -0.96 \\
\hline YX-07 12 & 178 & 0.027195 & 0.001181 & 0.282402 & 0.000018 & -13.1 & -9.3 & 0.6 & 1206 & 1811 & -0.96 \\
\hline YX-07 14 & 178 & 0.028510 & 0.001198 & 0.282403 & 0.000021 & -13.0 & -9.3 & 0.7 & 1206 & 1809 & -0.96 \\
\hline
\end{tabular}

\section{Discussion}

\subsection{Formation Ages}

The Xintaimen basin in Western Liaoning was well-known in recent years because of a large number of the Jehol biota fossils in the lacustrine sediments, such as the Liaoxitriton zhongjiani and associated Eosestheria and Liaoningocladusboii [44,45]. It consists of the Lower Cretaceous Yixian Formation and/or Jiufotang Formation. Further research from Sun et al. conducted ${ }^{40} \mathrm{Ar} /{ }^{39} \mathrm{Ar}$ dating of widely developed volcanic rocks, which indicated their likely formation in the late Early Cretaceous or the early Late Cretaceous (93-110 Ma) [46]. However, the latest zircon $\mathrm{U}-\mathrm{Pb}$ dating results of volcanic rocks in this paper show that the Xintaimen basin also developed a large range of Early Jurassic acidic volcanic rocks, with a formation age of 178.6-181.9 Ma. The rock assemblages are trachyandesite, trachydacite, a small amount of rhyolite and andesitic pyroclastic rocks, which are spatially distributed in the NNE or NS direction.

The Eastern Hebei and Western Liaoning areas on the eastern margin of the NCC were successively affected by the interaction of the Tethyan tectonic domain, the Paleo-Asian Ocean tectonic domain, and the Paleo-Pacific tectonic domain. Massive igneous rocks have been exposed in the Yanshan region located on the northern margin which is characterized by the superposition of multi-stage tectonic-magmatic activities [6,39,43,55,70,71]. The activity of Mesozoic vulcanism can be divided into four periods: Early Jurassic (Nandaling or Xinglonggou Period), Late Jurassic (Tiaojishan or Lanqi Period), Early Cretaceous (Zhangjiakou or Yixian Period), and Late Cretaceous (Daxingzhuang Period) [6,29,35-37,39,43,71,72]. Among these, the distribution range of Early Jurassic volcanic rocks is relatively limited and weak inactivity. The volcanic rocks are mainly composed of basalt, basaltic trachyandesite, andesite, trachyandesite, trachyte, and dacite [6,35-37,43]. The sporadic intermediate-basic volcanic rocks (174 Ma) from the Nandaling Formation in Xishan, Beijing, the intermediate volcanic rocks (202-177 Ma) from the Xinglonggou Formation in Beipiao, Western Liaoning, and the intermediate volcanic rocks (183-173 Ma) from the Haifanggou Formation in Beipiao, Western Liaoning are all products of volcanic activities in this period $[43,55,70,71]$, which is basically consistent with the dating results of this paper (178.6-181.9 Ma).

\subsection{Petrogenesis and Magma Source}

The Early Jurassic volcanic rocks in the Western Liaoning are a set of intermediateacidic rock assemblages, including trachyandesite, trachydacite, and a small amount of rhyolite and basaltic trachyandesite. From the perspective of petrochemical characteristics, 
Early Jurassic volcanic rocks have adakitic geochemical characteristics, such as high $\mathrm{SiO}_{2}$ (60.94-71.45 wt.\%), $\mathrm{Al}_{2} \mathrm{O}_{3}$ ( $\geq 14.41$ wt.\%), and $\mathrm{Na}_{2} \mathrm{O}$ ( $\geq 3.46$ wt.\%), with high Sr content between 395-1022 ppm (except YX-07, YX-08), low Y (5.74-15.68 ppm, <18 ppm), and Yb (0.55-1.58 ppm, <1.9 ppm). The samples are enriched in LREEs and LILEs, depleted in HREEs and HFSEs $[2,73]$, without Eu anomalies $\left(\mathrm{Eu} / \mathrm{Eu}^{*}=0.71-1.07\right)$, and fall into the adakitic rocks area in $(\mathrm{Yb})_{\mathrm{N}^{-}}(\mathrm{LA} / \mathrm{Yb})_{\mathrm{N}}$ and $\mathrm{Y}$-Sr/Y diagrams (Figure 9a,b). Therefore, this set of Early Jurassic intermediate-acidic volcanic rocks should be adakitic rocks.
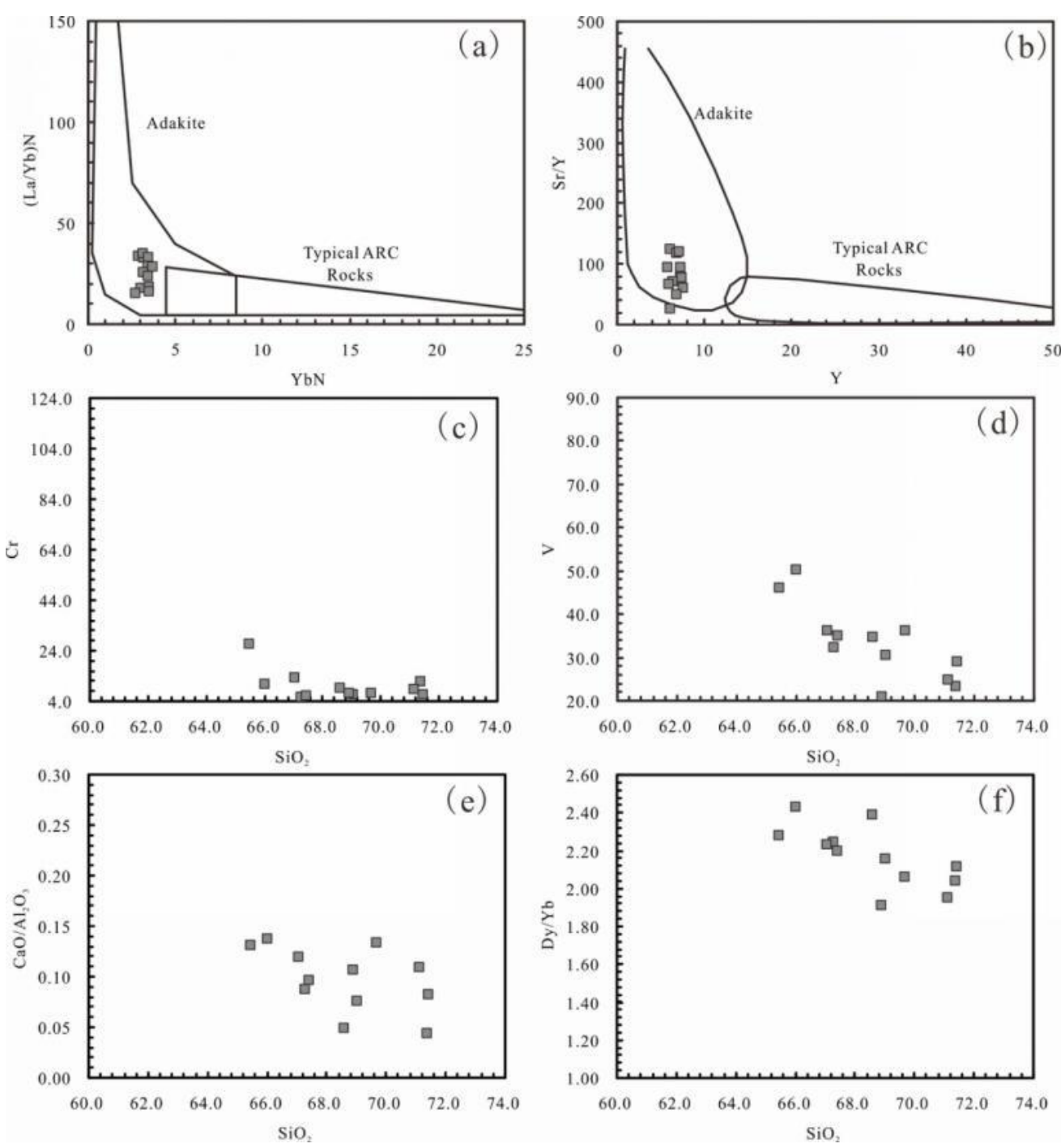

Figure 9. Discriminant diagram of adakite rocks and $\mathrm{SiO}_{2}$ concordant diagram. (a) $(\mathrm{La} / \mathrm{Yb})_{\mathrm{N}}-\mathrm{Yb}_{\mathrm{N}}$ diagram; (b) Sr/Y-Y diagram; (c) Cr vs. $\mathrm{SiO}_{2}$ diagram; (d) V vs. $\mathrm{SiO}_{2}$ diagram; (e) $\mathrm{Cao}_{2} \mathrm{Al}_{2} \mathrm{O}_{3}$ vs. $\mathrm{SiO}_{2}$ diagram. (f) $\mathrm{Dy} / \mathrm{Yb}$ vs. $\mathrm{SiO}_{2}$ diagram.

The rocks can be produced by the partial melting of the subducting oceanic crust interacting with the overlying mantle peridotite $[2,73]$, by the crystallization differentiation of basaltic magma and crustal contamination [3], by partial melting of basaltic rocks and eclogite in the delamination lower crust $[6,74,75]$, or by partial melting of ancient (thickened) basaltic lower crust $[35,36,76,77]$. However, the high $\mathrm{K}_{2} \mathrm{O}$ content, $\mathrm{K}_{2} \mathrm{O} / \mathrm{Na}_{2} \mathrm{O}$ and $\mathrm{Sr} / \mathrm{Y}$ ratios, low HREEs, weak negative Eu anomaly, and inherited zircon with crystalline basement age indicate that the volcanic rocks cannot have been formed in the partial melting of subducted oceanic plate [37,71]. At the same time, the $\mathrm{SiO}_{2}$ content of most samples is higher $(>66 \%)$, with low $\mathrm{MgO}, \mathrm{Mg}^{\#}, \mathrm{Cr}, \mathrm{Ni}$, and other characteristics, which are also different from the partial melting characteristics of the hydrated mantle [2,73]. 
Lower $\mathrm{MgO}, \mathrm{Cr}, \mathrm{Ni}, \mathrm{Sc}$, Co contents and $\mathrm{Mg}^{\#}$ values [75,78], combined with the fact that Early Jurassic basalts have not been found in the Xintaimen area, indicate that the initial magma was not the product of crystallization differentiation of basaltic magma, or was not affected by mantle magma contamination, or did not interact with mantle peridotite, which excludes it as the product of partial melting of the delamination lower crust (Figure 10d). Low $\mathrm{Ce} / \mathrm{Pb}(<3.6)$, Th, and $\mathrm{U}$ values indicate that lower crust materials are involved in the source area or magma evolution [79], and their higher Sr/Y ratios may be the characteristics of the inherited source area. In addition, the linear relationship between the major elements and $\mathrm{SiO}_{2}$ content suggests the existence of fractional crystallization during the magmatic evolution [80]. Furthermore, the Lu-Hf isotope results show that the value of $\varepsilon_{\mathrm{Hf}}(\mathrm{t})$ ranges from -11.6 to -7.4 , and the two-stage model ages $\left(\mathrm{T}_{\mathrm{DM} 2}\right)$ range from 1692 to $1958 \mathrm{Ma}$, indicating that its magma source should be the partial melting of the lower crust of the Proterozoic (Figure 8). Therefore, this set of intermediate-acidic adakitic volcanic rocks originated from partial melting of the Proterozoic basaltic rocks in the lower crust of the NCC, nevertheless mantle-derived magma may also be involved. The partial melting of the lower crust caused by the underplating of basaltic magma is considered to be one of the main mechanisms for the formation of Mesozoic adakitic rocks in North China $[5,35,36,76,77]$. In the inland areas far from the subduction zone, the underplating event of mantle-derived basaltic magma cannot only thicken the lower crust, but also provide huge heat energy to promote partial melting of the lower crust rock to form adakitic magma [5,81]. Early-Middle Jurassic zircon ages in the lower crustal xenoliths of the Hannuo Dam in North China, indicate that there was a magmatic underplating event during the Early Jurassic-Middle Jurassic [25,55,82]. The underplating basaltic magma is generally considered to be not involved in the melting process or to play a lower role, resulting in the formation of adakitic magma with low $\mathrm{Cr}, \mathrm{Ni}, \mathrm{Co}, \mathrm{SC}, \mathrm{Mg}^{\#}$, and $\mathrm{MgO}$ contents, which is similar to the geochemical characteristics of Early Jurassic intermediateacidic volcanic rocks in the study area. The underplating basaltic magma may also have crust-mantle interaction with the lower crustal magma, forming a small amount of basaltic magma, and leading to the abnormal value of $\varepsilon_{\mathrm{Hf}}(\mathrm{t})$ [52]. Therefore, during the process of basaltic magma in the NCC underplating the basic lower crust in the Early Jurassic, the mantle-derived magma underwent fractional crystallization while heating the overlying ancient (Proterozoic) lower crust, and part of the thickened crust melted to form adakitic magma. Because the $\mathrm{Ni}, \mathrm{Cr}$ concentrations and $\mathrm{Mg}^{\#}$ values have not increased significantly, adakitic magma may not be mixed with differentiated mantle-derived magma, or only mixed with a small amount of differentiated mantle-derived magma. Then, the acidic magma chamber was formed by fractional crystallization of mafic minerals, and finally, it rose rapidly and was expelled from the surface to form intermediate-acidic volcanic rocks with high Sr/Y and low REE. 

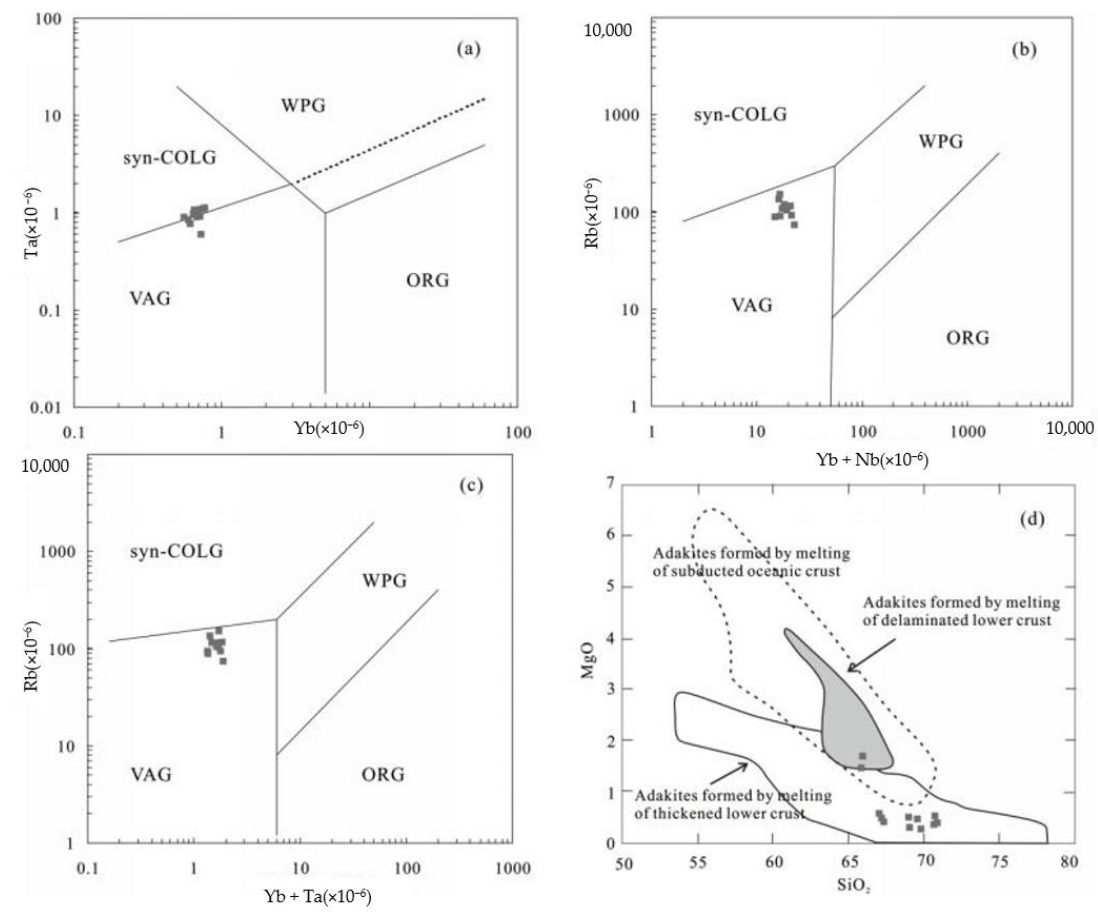

Figure 10. Tectonic discrimination diagrams (a-c) and $\mathrm{SiO}_{2}-\mathrm{MgO}$ diagram (d), after Lai and Qi [83]) for the Early Jurassic volcanic rocks.

\subsection{Geological Implication}

Western Liaoning is located in the superposition of the Tethys tectonic domain, the Paleo-Asian Ocean tectonic domain and the Paleo-Pacific tectonic domain [84]. It is one of the important regions for studying intracontinental orogeny, Yanshan movement, lithospheric thinning, and destruction of NCC $[6,18,30,85,86]$. The Yanshan region experienced large-scale tectonic deformation and magmatic activities, and developed a large-scale NE-NNE-trending fault basin. During the Mesozoic, it experienced the transition from convergence regime dominated by the Paleo-Asian Ocean tectonic domain to the subduction regime dominated by the Paleo-Pacific tectonic domain [29,51,72,77,87-89], which led to strong tectonism, magmatism, and mineralization $[40,41,90]$.

The Early Jurassic volcanic rocks are sporadically distributed in Eastern Hebei and Western Liaoning, including the Nandaling Formation in Xishan, Beijing, Xinglonggou Formation in Chengde, Hebei and Western Liaoning, and Haifanggou Formation in Western Liaoning [6,35-37,39,43,71]. Discussions on their tectonic backgrounds continue to this day. For example, the products of the Mongolia-Okhotsk Ocean closure and the Farallon Plate double-subduction [42], the intraplate environment, which is related to the subduction of the Paleo-Pacific plate [43], and the long-range effect of the Mongolia-Okhotsk Ocean closure [91] and so on. In general, the Early Jurassic volcanic rocks all have the characteristics of adakitic rocks, and their genesis is closely related to the basaltic magma underplating event $[6,36,37,39,42,43,91]$.

The Early Jurassic volcanic rocks are mainly a set of intermediate-acidic rock assemblages, including trachyandesite, trachydacite, and a small amount of rhyolite, which are similar to the rock assemblages in the active continental margin environment [92,93]. The major elements indicate that most of the Early Jurassic volcanic rocks belong to the high-K calc-alkaline series of rocks, and a small number of them belong to the alkaline series. The calc-alkaline rock assemblage is considered to be an effective indicator of paleosubduction [38]. The trace elements show that the volcanic rocks are enriched in LREEs and LILEs (such as $\mathrm{Ba}, \mathrm{Rb}, \mathrm{K}, \mathrm{Pb}$ ), and depleted in HREEs and HFSEs (such as $\mathrm{Nb}, \mathrm{Ta}, \mathrm{P}, \mathrm{Ti}$, $\mathrm{Y})$ (Figure 7), indicating the geochemical characteristics of the igneous rocks in the active continental margin $[80,94,95]$. In addition, the contemporaneous Early-Middle Jurassic 
granitic rock assemblages in the Western Liaoning are monzogranite and syenogranite. The major elements indicate by the high-K calc-alkaline series are metaluminous-weakly peraluminous, and is a I type granite. The trace elements are enriched in LREEs and LILEs, depleted in HREEs and HFSEs [96], similar to the geochemical characteristics of volcanic rocks, indicating the geochemical characteristics of igneous rocks in active continental margin similar to volcanic rocks. The common presented strong $\mathrm{Nb}$ and Ta depletion (Figure 7) implies in a volcanic island arc tectonic environment associated with subduction. In the tectonic environment discriminant diagram (Figure 10a-c), the samples also show the geodynamic setting of the subducted volcanic island arc, which belongs to the adakitic rock formed by partial melting of the thickened lower crust (Figure 10d), and the active continental margin environment $[80,97]$. This may be related to the long-range effect of the Paleo-Pacific plate subduction, but the influence of the Mongolia-Okhotsk Ocean closure is not excluded.

Before the Early Jurassic, a large number of fold structures with nearly EW trending and thrust nappes structures with hanging wall pointing to the south were developed in the Eastern Hebei and Western Liaoning. The whole region was under a compressive stress field of nearly $\mathrm{SN}$ trend, which may be related to the compressive deformation in the SN direction caused by the subduction of the Paleo-Asian Ocean in the region $[51,98,99]$. Subsequently, the Early Jurassic entered the joint influence period of the Paleo-Pacific tectonic domain and Mongolian-Okhotsk tectonic domain [38,100-102], and the transformation occurred from post-orogenic extension to intracontinental compression orogeny. The regional lower crust thickened under the dual-long-range effect of the MongoliaOkhotsk Ocean closure and the Paleo-Pacific plate subduction $[43,103]$. In this thickened lower crust environment, the enriched lithospheric mantle partially melted, and the basaltic magma underplated into the ancient lower crust, resulting in the partial melting to form intermediate-acidic adakitic volcanic rocks (Figure 11).

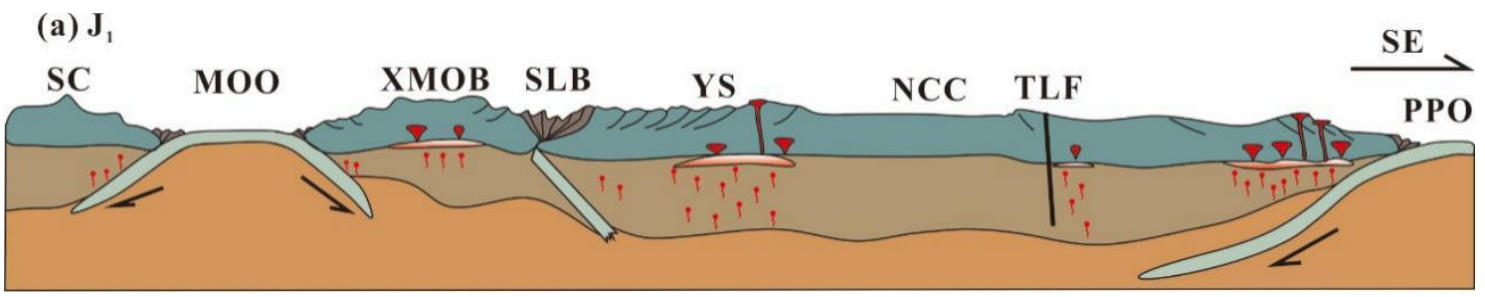

Figure 11. Tectonic evolution of the northern North China Craton during Early Jurassic (modified after Ma, 2013 [71]). $\mathrm{MOO}=$ Mongolia-Okhotsk Ocean; NCC = North China Craton; PPO = Paleo-Pacific Ocean; SC = Siberian Craton; $\mathrm{XMOB}=$ Xing'an Mongolian Orogenic Belt; SLB = Solonker-Linxi Suture Belt; YS = Yanshan orogen; TLF = Tan-Lu Fault.

\section{Conclusions}

Based on the study of petrography, zircon $\mathrm{U}-\mathrm{Pb}$ geochronology, geochemistry, and zircon Hf isotope of Early Jurassic volcanic rocks in the Western Liaoning, the following main conclusions were drawn:

(1) The latest zircon $\mathrm{U}-\mathrm{Pb}$ geochronology results show that in addition to the Early Cretaceous volcanic rocks, a wide range of Early Jurassic intermediate-acidic volcanic rocks also developed in the Xintaimen basin. The formation age is 178.6-181.9 Ma, and the rocks are spatially distributed in the NE direction.

(2) The Early Jurassic volcanic rocks are mainly composed of trachyandesite and a small amount of rhyolite. The geochemical characteristics show high contents of $\mathrm{SiO}_{2}$, $\mathrm{Al}_{2} \mathrm{O}_{3}$, and $\mathrm{Na}_{2} \mathrm{O}$, high contents of $\mathrm{Sr}$ and low contents of $\mathrm{Y}$ and $\mathrm{Yb}$, enrichment in LREEs and LILEs, and depletion in HREEs and HFSEs, without Eu anomalies, indicating that they are a set of intermediate-acidic adakitic volcanic rock in high-K calc-alkaline series.

(3) The Early Jurassic Western Liaoning was under the long-range tectonic effects of the closure of the Mongolia-Okhotsk Ocean and the subduction of the Paleo-Pacific plate, 
which caused the basaltic magma to invade the lower crust of the North China Craton. The mantle-derived magma was separated and crystallized while heating the Proterozoic lower crust, part of the thickened crust melted to form intermediate-acidic adakitic volcanic rocks.

Author Contributions: Z.-W.S., C.-Q.Z. and C.-Y.L. conceived of the presented idea, designed the experiments and verified the data together. The article is originally written and revised by the corresponding author, C.-Q.Z., the other authors are also responsible for many revisions. The financial support for this study was mainly secured by C.-Q.Z., X.-C.X. and C.-Y.L., B.L., Q.-B.W., Y.-L.Z., C.-G.C. and Z.-X.W. digitalized the geological map and performed LA-ICP-MS dating and geochemistry analysis along with Z.-W.S. All authors have read and agreed to the published version of the manuscript.

Funding: This project was financially co-supported by the National Key R\&D Program of China (Grant No. 2017YFC0601401), National Natural Science Foundation of China (No. 41472164, 41872192, 41972215 and 41730210), and Self-determined Foundation of Key Laboratory of Mineral Resources Evaluation in Northeast Asia, Ministry of Natural Resources, China (Grant No. DBY-ZZ-18-09).

Institutional Review Board Statement: Not applicable.

Informed Consent Statement: Not applicable.

Data Availability Statement: The data presented in this study are available in this article.

Acknowledgments: We thank Yujie Hao from the Key Laboratory of Mineral Resources Evaluation in Northeast Asia, Ministry of Natural Resources, for his kindly help with the analysis of the zircon LA-ICP-MS U-Pb ages. Thanks also due to Qi Zheng from the School of Foreign Language Education, Jilin University, for linguistic review which significantly improved the manuscript.

Conflicts of Interest: The authors declare no conflict of interest.

\section{References}

1. Kay, R.W. Aleutian magnesian andesites: Melts from subducted Pacific ocean crust. J. Volcanol. Geotherm. Res. 1978, 4, 117-132. [CrossRef]

2. Defant, M.J.; Drummond, M.S. Derivation of some modern arc magmas by melting of young subducted lithosphere. Nature 1990, 347, 662-665. [CrossRef]

3. Castillo, P.R.; Janney, P.E.; Solidum, R.U. Petrology and geochemistry of Camiguin Island, southern Philippines: Insights to the source of adakites and other lavas in a complex arc setting. Contrib. Mineral. Petrol. 1999, 134, 33-51. [CrossRef]

4. Defant, M.J.; Kepezhinskas, P. Adakites: A review of slab melting over the past decade and the case for a slab-melt component in arcs. EOS Trans. Am. Geophys. Union 2001, 82, 68-69.

5. Atherton, M.P.; Petford, N. Generation of sodium-rich magmas from newly underplated basaltic crust. Nature 1993, 362, 144-146. [CrossRef]

6. Gao, S.; Rudnick, R.L.; Yuan, H.L. Recycling lower continental crust in the North China Craton. Nature 2004, $432,92-897$. [CrossRef]

7. Castillo, P.R. An overview of adakite petrogenesis. Chin. Sci. Bull. 2006, 3, 257-268. [CrossRef]

8. Castillo, P.R. Adakite petrogenesis. Lithos 2012, 134, 134-135. [CrossRef]

9. Macpherson, C.G.; Dreher, S.T.; Thirlwall, M.F. Adakites without slab melting: High pressure differentiation of island arc magma, Mindanao, the Philippines. Earth Planet. Sci. Lett. 2006, 243, 581-593. [CrossRef]

10. Moyen, J.F. High Sr/Y and La/Yb ratios: The meaning of the "adakitic signature". Lithos 2009, 112, 556-574. [CrossRef]

11. Richards, J.P.; Kerrich, R. Special paper: Adakite-like rocks: Their diverse origins and questionable role in metallogenesis. Econ. Geol. 2007, 102, 537-576. [CrossRef]

12. Liu, D.Y.; Nutman, A.P.; Compston, W.; Wu, J.S.; Shen, Q.H. Remnants of $\geq 3800$ Ma crust in the Chinese part of the Sino-Korean craton. Geology 1992, 20, 339-342. [CrossRef]

13. Zhao, G.C.; Sun, M.; Wilde, S.A.; Li, S.Z. Late Archean to Paleoproterozoic evolution of the North China Craton: Key issues revisited. Precambrian Res. 2005, 136, 177-202. [CrossRef]

14. Zhao, G.C.; Cawood, P.A.; Li, S.Z.; Wilde, S.A.; Sun, M.; Zhang, J.; He, Y.H.; Yin, C.Q. Amalgamation of the North China Craton: Key issues and discussion. Precambrian Res. 2012, 222-223, 55-76. [CrossRef]

15. Wan, Y.S.; Song, B.; Liu, D.Y.; Wilde, S.A.; Wu, J.S.; Shi, Y.R.; Yin, X.Y.; Zhou, H.Y. SHRIMP U-Pb zircon geochronology of Palaeoproterozoic metasedimentary rocks in the North China Craton: Evidence for a major Late Palaeoproterozoic tectonothermal event. Precambrian Res. 2006, 149, 249-271. [CrossRef]

16. Geng, Y.S.; Du, L.L.; Ren, L.D. Growth and reworking of the early Precambrian continental crust in the North China Craton: Constraints from zircon Hf isotopes. Gondwana Res. 2012, 21, 517-529. [CrossRef] 
17. Zhai, M.G. Cratonization and the Ancient North China Continent: A summary and review. Sci. China Earth Sci. 2011, 54, 1110-1120. [CrossRef]

18. Davis, G.A.; Meng, J.F.; Cao, W.R.; Du, X.Q. Triassic and Jurassic Tectonics in the Eastern Yanshan Belt, North China: Insights from the Controversial Dengzhangzi Formation and Its Neighboring Units. Earth Sci. Front. 2009, 16, 69-86. [CrossRef]

19. Jahn, B.M.; Griffin, W.L.; Windley, B. Continental growth in the Phanerozoic: Evidence from Central Asia. Tectonophysics 2000, 328, vii-vix. [CrossRef]

20. Wu, F.Y.; Lin, J.Q.; Wilde, S.A.; Zhang, X.O.; Yang, J.H. Nature and significance of the Early Cretaceous giant igneous event in eastern China. Earth Planet. Sci. Lett. 2005, 233, 103-119. [CrossRef]

21. Wu, F.Y.; Sun, D.Y.; Ge, W.C.; Zhang, Y.B.; Grant, M.L.; Wilde, S.A.; Jahn, B.M. Geochronology of the Phanerozoic Granitoids in Northeastern China. J. Asian Earth Sci. 2011, 41, 1-30. [CrossRef]

22. Menzies, M.A.; Fan, W.; Zhang, M. Palaeozoic and Cenozoic lithoprobes and the loss of $>120$ km of Archaean lithosphere, Sino-Korean craton, China. J. Geol. Soc. 1993, 76, 71-81. [CrossRef]

23. Liang, C.Y.; Liu, Y.J.; Hu, Z.H.; Li, X.B.; Li, W.M.; Zheng, C.Q.; Neubauer, F.; Zhang, Q. Provenance study from petrography and geochronology of Middle Jurassic Haifanggou Formation in Xingcheng Basin, western Liaoning Province. Geol. J. 2020, 55, 2420-2446. [CrossRef]

24. Liu, S.F.; Zhang, J.F.; Hong, S.Y.; Ritts, B.D. Early Mesozoic basin development and its response to thrusting in the Yanshan fold-and-thrust belt, China. Int. Geol. Rev. 2007, 49, 1025-1049. [CrossRef]

25. Zhang, H.F.; Zhu, R.X.; Santosh, M.; Ying, J.F.; Su, B.X.; Hu, Y. Episodic widespread magma underplating beneath the North China Craton in the Phanerozoic: Implications for craton destruction. Gondwana Res. 2013, 23, 95-107. [CrossRef]

26. Zhu, G.; Jiang, D.Z.; Zhang, B.L.; Chen, Y. Destruction of the eastern North China Craton in a backarc setting: Evidence from crustal deformation kinematics. Gondwana Res. 2012, 22, 86-103. [CrossRef]

27. Chang, S.C.; Zhang, H.C.; Hemming, S.R.; Mesko, G.T.; Fang, Y. ${ }^{40} \mathrm{Ar} /{ }^{39} \mathrm{Ar}$ age constraints on the Haifanggou and Lanqi formations: When did the first flowers bloom? Geol. Soc. Spec. Publ. 2014, 378, 277-284. [CrossRef]

28. Chang, S.C.; Gao, K.Q.; Zhou, C.F.; Jourdan, F. New chronostratigraphic constraints on the Yixian Formation with implications for the Jehol Biota. Palaeogeogr. Palaeoclimatol. Palaeoecol. 2017, 487, 399-406. [CrossRef]

29. Davis, G.A. The late Jurassic Tuchengzi/Houcheng Formation of the Yanshan fold-thrust belt: An analysis. Earth Sci. Front. 2005, 12,331-345.

30. Gao, H.L.; Zhao, Y.; Ye, H.; Zhang, S.H.; Liu, J.; Wang, G.C. Dating Jurassic volcanic rocks in the Western Hills of Beijing, North China: Implications for the initiation of the Yanshanian tectonism and subsequent thermal events. J. Asian Earth Sci. 2018, 161, 164-177. [CrossRef]

31. Jiang, B.Y.; Sha, J.S. Late Mesozoic stratigraphy in western Liaoning, China: A review. J. Asian Earth Sci. 2006, $28,205-217$. [CrossRef]

32. Liu, S.F.; Su, S.; Zhang, G.W. Early Mesozoic basin development in North China: Indications of cratonic deformation. J. Asian Earth Sci. 2013, 62, 221-236. [CrossRef]

33. Sha, J.G. Cretaceous stratigraphy of northeast China: Non-marine and marine correlation. Cretac. Res. 2007, 28, 146-170. [CrossRef]

34. Swisher, C.C., III; Wang, X.L.; Zhong, Z.H.; Wang, Y.Q.; Jing, F.; Zhang, J.Y.; Xing, X.; Zhang, F.C.; Wang, Y. Further support for a Cretaceous age for featured dinosaur beds of Liaoning Province, China: New ${ }^{40} \mathrm{Ar} /{ }^{39} \mathrm{Ar}$ dating of the Yixian and Tuchengzi formations. Chin. Sci. Bull. 2002, 47, 135-138.

35. Li, W.P. Geochemical characteristics of the early Jurassic dacites of the Xinglonggou Formation in Beipiao area, west Liaoning province. Acta Petrol. Sin. 2006, 22, 1608-1616. (In Chinese with English abstract)

36. Li, W.P. Geochemical Characteristics of the Middle Jurassic volcanic rocks of Haifanggou Formation, Western Liaoning Province, North China. Earth Sci. 2013, 38, 1153-1168. (In Chinese with English abstract)

37. Li, X.Y.; Fan, W.M.; Guo, F.; Wang, Y.J.; Li, C.W. Modification of the lithospheric mantle beneath the northern North China Block by the Paleo-Asian Ocean: Gechemical evidence from mafic volcanic rocks of the Nandaling Formation in the Xishan area, Beijing. Acta Petrol. Sin. 2004, 20, 557-566. (In Chinese with English abstract)

38. Xu, W.L.; Wang, F.; Pei, F.P.; Meng, E.; Tang, J.; Xu, M.J.; Wang, W. Mesozoic tectonic regimes and regional ore-forming background in NE China: Constraints from spatial and temporal variations of Mesozoic volcanic rock associations. Acta Petrol. Sin. 2013, 29, 339-353. (In Chinese with English abstract)

39. Yang, W.; Li, S.G. Geochronology and geochemistry of the Mesozoic volcanic rocks in Western Liaoning: Implications for lithospheric thinning of the North China Craton. Lithos 2008, 102, 9-18. [CrossRef]

40. Zhu, R.X.; Chen, L.; Wu, F.Y.; Liu, J.L. Timing, scale and mechanism of the destruction of the North China Craton. Sci. China Earth Sci. 2011, 54, 789-797. (In Chinese with English abstract) [CrossRef]

41. Zhu, R.X.; Xu, Y.G.; Zhu, G.; Zhang, H.F.; Xia, Q.K.; Zheng, T.Y. Destruction of the North China Craton. Sci. China Earth Sci. 2012, 55, 1565-1587. (In Chinese with English abstract) [CrossRef]

42. Meng, F.C.; Liu, J.Q.; Cui, Y.; Gao, J.L.; Liu, X.; Tong, Y. Mesozoic tectonic regimes transition in the Northeast China: Constriants from temporal-spatial distribution and associations of volcanic rocks. Acta Petrol. Sin. 2014, 30, 3569-3586. (In Chinese with English abstract) 
43. Wu, G.; Li, Z.T.; Wang, W.W. Geochemical features and its geological implication of Middle Mesozoic Haifanggou Formation in West Liaoning. Acta Petrol. Miner. 2004, 23, 97-105. (In Chinese with English abstract)

44. Dong, Z.M.; Wang, Y. A new urodele (Liaoxitriton zhongjianigen. et sp. Nov.) from the Early Cretaceous of western Liaoning Province, China. Vertebr. Plasiatica 1998, 36, 159-172. (In Chinese with English abstract)

45. Zhang, L.J.; Gao, K.Q.; Wang, L.X. New discovery of salamander fossils from the Yixian Formation in western Liaoning. Geol. Bull. China 2004, 23, 799-801. (In Chinese with English abstract)

46. Sun, R.S.; Ji, J.Q.; Gao, K.Q.; Zhang, Y.; Zhou, J.; Ma, F.; Xu, Q.Q. ${ }^{40} \mathrm{Ar} /{ }^{39}$ Ar dating of volcanic rocks and constraints for stratum age of Xintaimen area in western Liaoning. Acta Petrol. Sin. 2010, 26, 3397-3410. (In Chinese with English abstract)

47. Huang, D.Y. Jurassic integrative stratigraphy and timescale of China. Sci. China Earth Sci. 2019, 62, 223-255. (In Chinese with English abstract) [CrossRef]

48. Zhou, J.B.; Li, L. The Mesozoic accretionary complex in Northeast China: Evidence for the accretion history of Paleo-Pacific subduction. J. Asian Earth Sci. 2017, 145, 91-100. [CrossRef]

49. Liang, C.Y.; Liu, Y.J.; Zheng, C.Q.; Li, W.M.; Neubauer, F.; Zhang, Q.; Zhang, D. Deformation patterns and timing of the thrustnappe structures in the Mohe Formation in Mohe Basin, Northeast China: Implication of the closure timing of Mongol-Okhotsk Ocean. Geol. J. 2019, 54, 746-769. [CrossRef]

50. Liang, C.Y.; Liu, Y.J.; Zheng, C.Q.; Li, W.M.; Neubauer, F.; Zhang, Q. Macro-and microstructural, textural fabrics and deformation mechanism of calcite Mylonites from Xar Moron-Changchun Dextral Shear Zone, Northeast China. Acta Geol. Sin. Engl. Ed. 2019, 93, 1477-1499. [CrossRef]

51. Dong, S.W.; Zhang, Y.Q.; Zhang, F.Q.; Cui, J.J.; Chen, X.H.; Zhang, S.H.; Miao, L.C.; Li, J.H.; Shi, W.; Li, Z.H.; et al. Late Jurassic-early Cretaceous continental convergence and intracontinental orogenesis in East Asia: A synthesis of the Yanshan revolution. J. Asian Earth Sci. 2015, 114, 750-770. [CrossRef]

52. Lin, B. Geochemistry and Petrogenesis of Mesozoic Volcanic Rocks in the Geological Corridor of Western Liaoning. Ph.D. Thesis, Jilin University, Changchun, China, 2017; pp. 18-24.

53. Dai, L.M.; Li, S.Z.; Li, Z.H.; Somerville, I.; Suo, Y.H.; Liu, X.C.; Gerya, T.; Santosh, M. Dynamics of exhumation and deformation of HP-UHP orogens in double subduction-collision systems: Numerical modeling and implications for the western Dabie orogen. Earth-Sci. Rev. 2018, 182, 68-84. [CrossRef]

54. Dong, Y.P.; Santosh, M. Tectonic architecture and multiple orogeny of the Qinling Orogenic Belt, Central China. Gondwana Res. 2016, 29, 1-40. [CrossRef]

55. Shao, J.A.; Zhang, H.F.; Liu, X.M.; Li, Z.T. Chronological record of the Early Mesozoic underplating in the northern margin of North China-U-Pb chronometry of zircons in the Late Mesozoic andesite from Western Liaoning. Prog. Nat. Sci. 2007, 17, 943-947. (In Chinese with English abstract)

56. Bureau of Geology and Mineral Resources of Liaoning Province. Regional Geology of Liaoning Province; Geological Publishing House: Beijing, China, 1989; pp. 438-460.

57. Liang, C.Y.; Liu, Y.J.; Song, Z.W.; Zhang, Q.; Yang, Y. Deformation pattern and age of Hulin complex in Heilongjiang province: Implications for subduction of the Paleo-pacific plate during the Early Cretaceous, eastern NE China. Acta Petrol. Sin. 2020, 36, 685-702. (In Chinese with English abstract)

58. Ludwig, K.R. ISOPLOT 3.0: A geochronological toolkit for Microsoft excel. Geochronol. Cent. 2003, 4, 1-72.

59. Andersen, T. Correction of common lead in U-Pb analyses that do not report ${ }^{204} \mathrm{~Pb}$. Chem. Geol. 2002, 192, 59-79. [CrossRef]

60. Hu, P.Y.; Liang, C.Y.; Zheng, C.Q.; Zhou, X.; Yang, Y.; Zhu, E.L. Tectonic Transformation and Metallogenesis of the Yanshan Movement during the Late Jurassic Period: Evidence from Geochemistry and Zircon U-Pb Geochronology of the Adamellites in Xingcheng, Western Liaoning, China. Minerals 2019, 9, 518. [CrossRef]

61. Hu, Z.C.; Liu, Y.S.; Gao, S.; Xiao, S.Q.; Zhao, L.S.; Günther, D.; Li, M.; Zhang, W.; Zong, K.Q. A “wire” signal smoothing device for laser ablation inductively coupled plasma mass spectrometry analysis. Spectrochim. Acta Part B At. Spectrosc. 2012, $78,50-57$. [CrossRef]

62. Corfu, F.; Hanchar, J.M.; Hoskin, P.W.O.; Kinny, P. Atlas of zircon textures. Rev. Mineral. Geochem. 2003, 53, 469-500. [CrossRef]

63. Irvine, T.N.; Baragar, W.R.A. A Guide to Chemical Classification of the Common Volcanic Rock. Can. J. Earth Sci. 1971, 8, 523-548. [CrossRef]

64. Peccerillo, R.; Taylor, S.R. Geochemistry of Eocene Calc-Alkaline Volcanice Rocks from the Kastamonu Area, Northern Turkey. Contrib. Mineral. Petrol. 1976, 58, 63-81. [CrossRef]

65. Maniar, P.D.; Piccoli, P.M. Tectonic Discrimination of Granitoids. Geol. Soc. Am. Bull. 1989, 101, 635-643. [CrossRef]

66. Sun, S.S.; McDonough, W.F. Chemical and Isotopic Systematics of Oceanic Basalts: Implications for Mmantle Composition and Processes. Geol. Soc. Spec. Publ. 1989, 42, 313-345. [CrossRef]

67. Boynton, W.V. Geochemistry of the rare earth elements: Meteorite studies. Rare Earth Elem. Geochem. 1984, 2, 63-114.

68. Yang, J.H.; Wu, F.Y.; Shao, J.A.; Xie, L.W.; Liu, X.M. In-Situ U-Pb dating and Hf isotopic analyses of zircons from volcanic rocks of the Houcheng and Zhangjiakou Formation in the Zhang-Xuan area, Northeast China. Earth Sci. 2006, 31, 71-80. (In Chinese with English abstract)

69. Wu, F.Y.; Li, X.H.; Zheng, Y.F.; Gao, S. Lu-Hf isotopic systematics and their applications in petrology. Acta Petrol. Sin. 2007, 23, 185-220. (In Chinese with English abstract) 
70. Zhao, Y.; Song, B.; Zhang, S.H.; Liu, J. Relict zircon chronology and its implications within the Jurassic Nandaling basaltic rocks in west Hills of Beijing. Earth Sci. Front. 2006, 13, 183-190. (In Chinese with English abstract)

71. Ma, Q. Triassic-Jurassic Volcanic Rocks in Western Liaoning: Implications for Lower Crustal Reworking and Lithospheric Destruction in the North Part of Eastern North China Craton. Ph.D. Thesis, China University of Geosciences, Wuhan, China, 2013; pp. 33-84.

72. Davis, G.A. The Yanshan belt of North China: Tectonics, adakitic magmatism, and crustal evolution. Earth Sci. Front. 2003, 10, 373-384.

73. Defant, M.J.; Drummond, M.S. Mount St. Helens: Potential example of the partial melting of the subducted lithosphere in a volcanic arc. Geology 1993, 21, 547-550. [CrossRef]

74. Yuan, H.L.; Liu, X.M.; Liu, Y.S.; Gao, S.; Ling, W.L. Geochemistry and U-Pb zircon geochronology of Late-Mesozoic lavas from Xishan, Beijing. Sci. China 2006, 49, 50-67. (In Chinese with English abstract) [CrossRef]

75. Baker, M.B.; Hirschmann, M.M.; Ghiorso, M.S. Compositions of near-solidus peridotite melts from experiments and thermodynamic calculations. Nature 1995, 375, 308-311. [CrossRef]

76. Kay, R.W.; Kay, S.M. Andean adakites: Three ways to make them. Acta Petrol. Sin. 2002, 18, 303-311.

77. Li, W.P.; Zhao, Y.; Li, X.H.; Lu, F.X.; Liang, X.R.; Tu, X.L. Genesis of the middle-later Jurassic volcanic rocks of Tiaojishan (Lanqi) period and its geodynamic implication, Yanshan Orogen. Acta Petrol. Sin. 2007, 23, 557-564. (In Chinese with English abstract)

78. Rapp, R.P.; Watson, E.B. Dehydration melting of metabasalt at 8-32 kbar: Implications for continental growth and crust-mantle recycling. J. Petrol. 1995, 36, 891-931. [CrossRef]

79. Huang, F.; He, Y.S. Partial melting of the dry mafic continental crust: Implications for petrogenesis of C-type adakites. Chin. Sci. Bull. 2010, 55, 2428-2439. (In Chinese with English abstract) [CrossRef]

80. Wilson, M. Igneous Petrogenesis. A Global Tectonic Approach; Unwin Hyman: Landon, UK, 1989; p. 466.

81. Han, B.F.; Kagami, H.; Li, H.M. Age and Nd-Sr isotopic geochemistry of the Guangtoushan alkaline granite, Hebei Province, China: Implications for early Mesozoic crust-mantle interaction in North China Block. Acta Geosci. Sin. 2004, 20, 74-87, (In Chinese with English abstract).

82. Xu, W.L.; Hergt, J.M.; Gao, S.; Pei, F.P.; Wang, W.; Yang, D.B. Interaction of adakitic melt-peridotite: Implications for the high-Mg\# signature of mesozoic adakitic rocks in the eastern North China Craton. Earth Planet. Sci. Lett. 2008, 265, $123-137$.

83. Lai, S.C.; Qin, J.F. Adakitic rocks derived from the partial melting of subducted continental crust: Evidence from the Eocene volcanic rocks in the northern Qiangtang block. Gondwana Res. 2013, 23, 812-824. [CrossRef]

84. Zhao, Y.; Yang, Z.Y.; Ma, X.H. Geotectonic Transition from Paleoasian system and Paleotethyan system to Paleopacific active continental margin in eastern Asia. Sci. Geol. Sin. 1994, 29, 105-119. (In Chinese with English abstract)

85. Li, S.Z.; Zhao, G.C.; Dai, L.M.; Liu, X.; Zhou, L.H.; Santosh, M.; Suo, Y.H. Mesozoic basin in eastern China and their bearing on the deconstruction of the North China Craton. J. Asian Earth Sci. 2012, 47, 64-79. [CrossRef]

86. Li, S.Z.; Suo, Y.H.; Li, X.Y.; Zhou, J.; Santosh, M.; Wang, P.C.; Wang, G.Z.; Guo, L.L.; Yu, S.Y.; Lan, H.Y.; et al. Mesozoic tectono-magmatic response in the East Asian ocean-continent connection zone to subduction of the Paleo-Pacific Plate. Earth-Sci. Rev. 2019, 192, 91-137. [CrossRef]

87. Guo, F.; Li, H.X.; Fan, W.M.; Li, J.Y.; Zhao, L.; Huang, M.W.; Xu, W.L. Early Jurassic subduction of the Paleo-Pacific Ocean in NE China: Petrologic and geochemical evidence from the Tumen mafic intrusive complex. Lithos 2015, 224-225, 46-60. [CrossRef]

88. Yan, D.P.; Zhou, M.F.; Song, H.L.; Wang, G.H.; Sun, M. Mesozoic extensional structures of the Fangshan tectonic dome and their subsequent reworking during collisional accretion of the North China block. J. Geol. Soc. 2006, 163, 127-142. [CrossRef]

89. Zhang, Q.; Liang, C.Y.; Liu, Y.J.; Zheng, C.Q.; Li, W.M. Final closure time of the Paleo-Asian Ocean: Implication from the provenance transformation from the Yangjiagou Formation to Lujiatun Formation in the Jiutai Area, NE China. Acta Geol. Sin. Engl. Ed. 2019, 93, 1456-1476. [CrossRef]

90. Windley, B.F.; Maruyama, S.; Xiao, W.J. Delamination/thinning of sub-continental lithospheric mantle under Eastern China: The role of water and multiple subduction. Am. J. Sci. 2010, 310, 1250-1293. [CrossRef]

91. Ma, Q.; Xu, Y.G.; Zheng, J.P.; Griffin, W.L.; Hong, L.B.; Ma, L. Coexisting Early Cretaceous high-Mg andesites and adakitic rocks in the North China Craton: The role of water in intraplate magmatism and cratonic destruction. J. Petrol. 2016, 57, 1279-1308. [CrossRef]

92. Pitcher, W.S. Granite Type and Tectonic Environment; Mountain Building Processes: London, UK, 1983; pp. 19-40.

93. Pitcher, W.S. The Nature and Origin of Granite, 2nd ed.; Chapman and Hall: London, UK, 1997; p. 387.

94. Gill, J.B. Orogenic Andesites and Plate Tectonics; Springer: New York, NY, USA, 1981; p. 390.

95. Kelemen, P.B.; Hangh, J.K.; Greene, A.R. One view of the geochemistry ofsubduction-related magmatic arcs, with an emphasis on primitive andesite and lower crust. Treatise Geochem. 2003, 3, 593-659.

96. Cui, F.H. Petrogenesis of Mesozoic Granitoids and Crustal Evolution in Xingcheng Area, Western Liaoning Province. Ph.D. Thesis, Jilin University, Changchun, China, 2015; pp. 32-107.

97. Deering, C.D.; Vogel, T.A.; Patino, L.C.; Alvarado, G.E. Origin of distinct silicic magma types from the Guachipelín Caldera, NW Costa Rica: Evidence for magma mixing and protracted subvolcanic residence. J. Volcanol. Geotherm. Res. 2007, 165, 103-126. [CrossRef]

98. Wang, T.; Zheng, Y.D.; Zhang, J.J.; Zeng, L.S.; Donskaya, T.; Li, G.L.; Li, J.B. Pattern and kinematic polarity of late Mesozoic extension in continental NE Asia: Perspectives from metamorphic core complexes. Tectonics 2011, 30, 1-27. [CrossRef] 
99. Cope, T.D.; Shultz, M.R.; Graham, S.A. Detrital record of Mesozoic shortening in the Yanshan belt, North China: Testing structural interpretations with basin analysis. Basin Res. 2007, 19, 253-272. [CrossRef]

100. Li, C.M.; Zhang, C.H.; Cope, T.D.; Lin, Y. Out-of-sequence thrusting in polycyclic thrust belts: An example from the Mesozoic Yanshan belt, North China Craton. Tectonics 2016, 35, 2082-2116. [CrossRef]

101. Zorin, Y.A. Geodynamics of the western part of the Mongolia-Okhotsk collisional belt, Trans-Baikal region (Russia) and Mongolia. Tectonophysics 1999, 306, 33-56. [CrossRef]

102. Maruyama, S.; Isozaki, Y.; Kimura, G.; Terabayashi, M. Paleogeographic maps of the Japanese Islands: Plate tectonic synthesis from $750 \mathrm{Ma}$ to the present. Island Arc 1997, 6, 121-142. [CrossRef]

103. He, Z.J.; Niu, B.G.; Zhang, X.Y. Late Jurassic thrusting and syntectonic sedimentary basin systems in the Chaoyang region, western Liaoning. Geol. Rev. 2007, 53, 152-165. (In Chinese with English abstract) 